\title{
Extracellular vesicles in bone and periodontal regeneration: current and potential therapeutic applications
}

\author{
Leila Gholami ${ }^{1}$, Vajihe Taghdiri Nooshabadi ${ }^{2,3}$, Shiva Shahabi ${ }^{4}$, Marzieh Jazayeri ${ }^{4}$, Rana Tarzemany ${ }^{5}$, \\ Zohreh Afsartala ${ }^{6,7}$ and Khatereh Khorsandi ${ }^{8^{*}}$
}

\begin{abstract}
Oral mesenchymal stem cells (MSCs) and their secretomes are considered important factors in the field of medical tissue engineering and cell free biotherapy due to their ease of access, differentiation potential, and successful therapeutic outcomes. Extracellular vesicles (EVs) and the conditioned medium (CM) from MSCs are gaining more attraction as an alternative to cell-based therapies due to the less ethical issues involved, and their easier acquisition, preservation, long term storage, sterilization, and packaging. Bone and periodontal regenerative ability of EVs and CM have been the focus of some recent studies. In this review, we looked through currently available literature regarding MSCs'EVs or conditioned medium and their general characteristics, function, and regenerative potentials. We will also review the novel applications in regenerating bone and periodontal defects.
\end{abstract}

Keywords: Extracellular vesicles, Mesenchymal stem cells, Bone regeneration, Periodontal regeneration

\section{Introduction}

Periodontitis is still considered as a globally prevalent disease [1]. The chronic presence of pathological factors may proceed to destruct the supporting periodontium of the teeth and lead to tooth loss. Early diagnosis of periodontitis prevents further structural damages to the periodontium, and it can be treated by removal of pathologic factors using scaling and root planning [2]. In the case of lost periodontal tissues, regeneration of the periodontium is considered as a challenging treatment. Numerous procedures and products have been developed and applied to regenerate lost periodontal tissue [3-7]. Such regenerative treatments are difficult and only effective in specific conditions with limited tissue reconstruction results, as the periodontium is a complex structure which possess various cell types [8].

${ }^{*}$ Correspondence: khorsandi.kh@ut.ac.ir

${ }^{8}$ Department of Photodynamic, Medical Laser Research Center, Yara Institute, ACECR, Tehran, Iran

Full list of author information is available at the end of the article
Bone, as a connective tissue, preserves and supports organs and tissues within the body. It is also one of the important structures of the periodontal tissues surrounding teeth. Bone remodeling is a lifelong process to preserve bone structure and function. Some conditions like aging, trauma, obesity, congenital abnormalities, surgical removal of a mass within the bone, and cancer metastases to the bone, may interfere with the normal balance of bone remodeling and increase the demand for an efficient therapy to regenerate the bone tissue [9-12]. Autogenous and allogenous bone grafts are currently considered as a gold standard in bone regenerative therapies. However, numerous complications including, morbidity at graft harvesting site, limited harvesting sources, graft versus host disease (GVHD), need for secondary surgery, infection, and non-union formation are associated with these treatments [13-17]. Therefore, a new, safe, and efficient therapy is highly demanded to overcome the existing limitations. Bone remodeling involves various cells, such as bone cells (osteoblasts, osteoclasts, mechanosensitive osteocytes, and bone marrow stem cells), immune cells

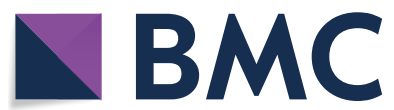

(c) The Author(s) 2021. This article is licensed under a Creative Commons Attribution 4.0 International License, which permits use, sharing, adaptation, distribution and reproduction in any medium or format, as long as you give appropriate credit to the original author(s) and the source, provide a link to the Creative Commons licence, and indicate if changes were made. The images or other third party material in this article are included in the article's Creative Commons licence, unless indicated otherwise in a credit line to the material. If material is not included in the article's Creative Commons licence and your intended use is not permitted by statutory regulation or exceeds the permitted use, you will need to obtain permission directly from the copyright holder. To view a copy of this licence, visit http://creativeco mmons.org/licenses/by/4.0/. The Creative Commons Public Domain Dedication waiver (http://creativecommons.org/publicdomain/ zero/1.0/) applies to the data made available in this article, unless otherwise stated in a credit line to the data. 
( $\mathrm{T}$ cells, dendritic cells, and monocytes), and articular cartilage cells [18]. Intercellular communication between cells is essential for bone remodeling [19]. This has directed recent studies towards investigating more suitable and efficient bone regenerative therapies especially when dealing with challenging defects that are beyond the spontaneously healing size.

Regenerative medicine is considered as a subdivision of translational medical science that focuses on identifying various approaches to efficiently replace or reestablish the normal structure and function of damaged tissues [20]. Stem cells have been considered as effective tools in regenerative medicine, with the potential to differentiate into various cell types, and having a wide range of applications including in tooth regeneration, wound healing, and treatment of various diseases $[21,22]$.

Oral tissues have been considered a suitable source of mesenchymal stem cells (MSCs), and the first dental derived stem cells were isolated from a dental pulp in 2000 [23]. Dental stem cells are regarded as an easily accessible and suitable source of stem cells with a wellknown regenerative capacity. Dental derived stem cells include multiple types such as dental pulp mesenchymal stem cells (DP-MSCs), stem cells from exfoliated deciduous teeth (SHED), stem cells from apical papilla (SCAP), periodontal ligament stem cells (PDLSCs), and dental follicle progenitor cells (DFPCs).There, still exists a search for finding more suitable stem cell origins in the oral cavity to be used in tissue regenerations and cell based therapies [24].

One of the secreted particles from MSCs is extracellular vesicle (EVs). EV is a term approved by International Society for Extracellular Vesicles (ISEV) for bilayer lipid membrane vesicles that are non-replicable, containing nucleic acids, proteins, lipids, and various signaling molecules [25]. Most eukaryotic cells secrete EVs, which have essential roles in intercellular communications. They carry active signals that can influence the activity of adjacent or distant recipient cells [26, 27]. It has been suggested that MSCs' paracrine activity is controlled by growth factors and survival signals, as well as EVs. Current investigations have shown the beneficial contribution of MSC derived EVs in MSCs' physiological functions [28]. Due to the challenges related to stem cell therapy, more recent studies have focused on other novel alternative regenerative methods such as cell free therapies on based paracrine signaling and use of such secreted particles to overcome these obstacles [29-33]. The investigation onstem cells and their mechanisms of action have revealed the important role of bioactive molecules of these cells and the media surrounding them [the conditioned media (CM)]. One of the most important secreted molecules that are released to the biological fluid or cell culture CM are EVs that show the same regenerative function as stem cells and can be considered as safe alternatives [34]. EVs' valuable advantages over stem cell therapy are their relative ease of preservation and sterilization, and the capability of long-term storage without the risk of losing their properties. These cellsecreted particles provide broad bio-signaling functions for various targeted cell types.

This capability has attracted attention to use EVs for transferring particular messages to multiple heterogeneous cells involved in tissue regeneration therapies such as craniofacial bone and tissue regenerations. The current review aims to summarize the available evidence on EVs' function and also their potential applications in bone and periodontal regeneration.

\section{General characteristics of EVs: biogenesis, components, and composition}

EVs have been previously classified into three main subtypes based on their cellular origin, size, or biogenesis. This includes (1) exosomes $(30-150 \mathrm{~nm})$ with an endocytic origin, (2) microvesicles (100-1000 nm) formed by budding of the plasma membrane, and (3) apoptotic bodies $(500 \mathrm{~nm}-2 \mu \mathrm{m})$ derived from dying cells (Fig. 1) [35]. Based on new guidelines and the fact that determining the exact biogenesis pathway of EV is still considered difficult, use of a more general term of EV is recommended. Moreover, for identifying EV subtypes, use of more operational terms which refer to either their physical characteristics such as size, density, biochemical composition, descriptions of conditions or cell of origin is suggested $[25,36]$.

Exosomes were first recognized in 1981 [37] and can be distinguished from other EVs by their protein and lipid composition. They can be secreted from almost all cell types and they can be found in body fluids (e.g., blood, breast milk, saliva, semen, and urine) [38, 39].

Exosomes are formed by the inward budding of endosomal membranes of multivesicular Endosome (MVE) and form intraluminal vesicles (ILV). These exosomes are released due to the fusion of the MVE with the plasma membrane [35].

Depending on their endosomal origin, EVs/exosomes may contain membrane transport and fusion proteins (Annexins, Rabs, flotillin), tetraspanins (CD9, CD63, CD81, CD82), heat shock proteins (Hsp70, Hsp 90), proteins associated with MVB formation, including Endosomal Sorting Complex Required for Transport (ESCRT) proteins, apoptosis-linked gene 2-interacting protein $\mathrm{X}$ (Alix), Tumor Susceptibility Gene 101 (TSG101), transmembrane receptors including MHC molecules and integrins as well as lipid-related proteins and phospholipases $[40,41]$. They also contain cytosolic proteins such 


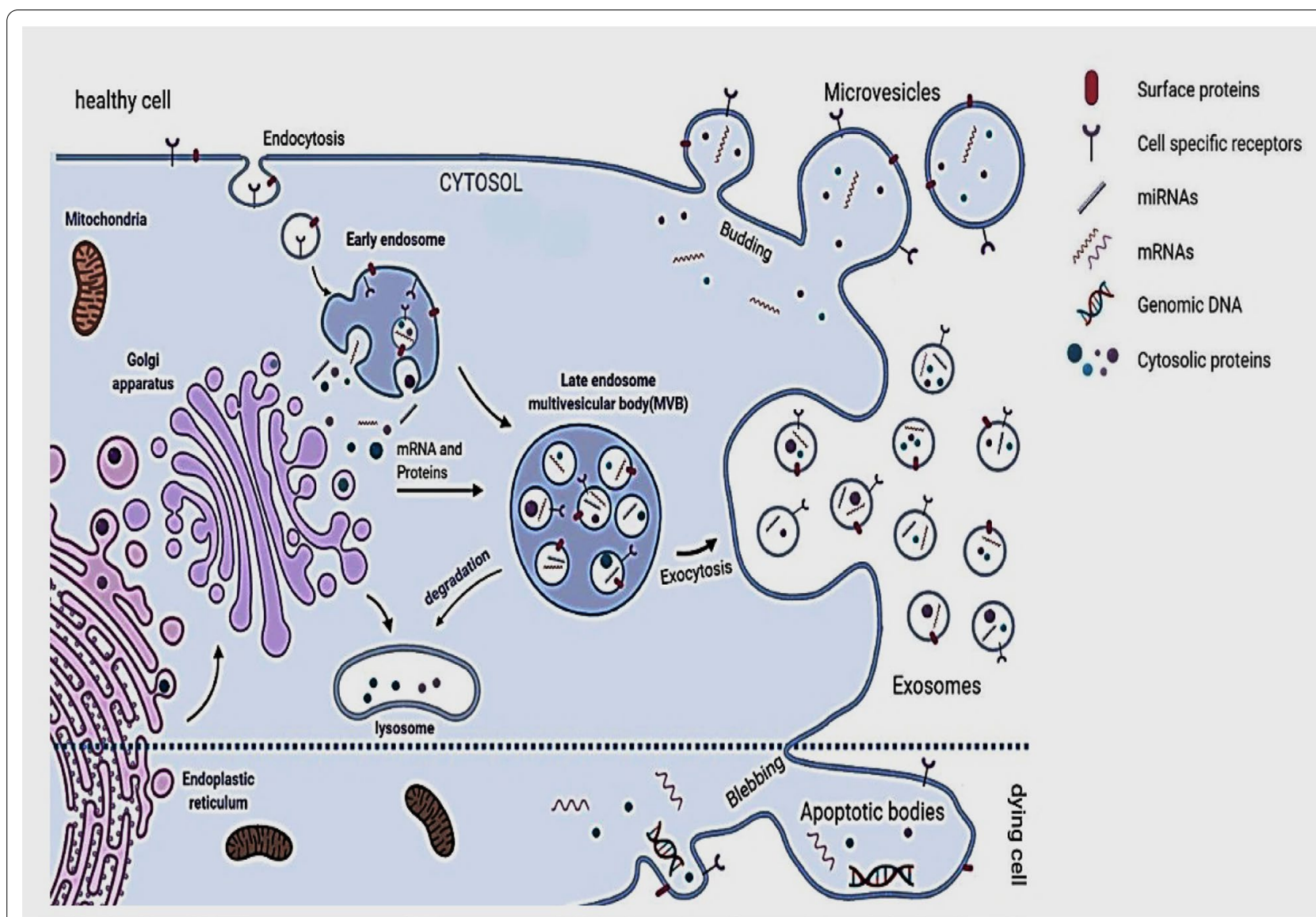

Fig. 1 Mechanisms of maturation and secretion of extracellular vesicles

as cytoskeletal proteins (Actin, Tubulin, Profilin, Cofilin) and various metabolic enzymes (AChE, GAPDH and Pyruvate kinase) [42]. Therefore, it should be taken into consideration that different sources of exosomes may cause a variation in these markers' expression. Commonly used markers of exosomes identification include tetraspanins, Alix, flotillin, TSG101, and Rab5b [27]. So far, more than 4400 different proteins in addition to the membrane proteins have been recognized as cargo for intercellular communication [43]. Moreover, exosomes contain specific raft-associated lipids such as cholesterol, ceramide, sphingolipids, and phosphoglycerides with long and saturated fatty-acyl chains [44-46]. The genomic molecules such as mRNA, miRNAs, and lncRNAs are mentioned as other exosome components associated with the regulation of gene expression. Exosome miRNA content is specific to the parental cell type and cell condition (e.g., inflammation and hypoxia) (Fig. 2) [47].

EVs are released in body fluids such as blood, semen and urine and may also be isolated from cell culture condition mediums [48-50].
Cell culture media are convenient sources of EVs that can result in a reproducible and high gain of EVs. Because of the high chance of EVs' contamination in culture media that are hard to distinguish during the isolation process, alternative ways such as EVs-depleted FBS are considered to prevent the influence on the type, cargo, and amount of released EVs [51-56]. Numerous factors affect EVs' secretion, including oxidative stress, hypoxia, and calcium ions [57]. These vesicles are distinguished by different sets of lipids, functionally active ribonucleic acids (e.g., mRNA, miRNA), and parental cell-derived cytosolic and membrane proteins [58-60]. EV-based therapies are relatively more convenient than cell-based therapeutics. However, identifying the EV separation, storage and retrieval methods which have been shown to significantly alters both the physical and biological properties of EVs, are challenging topics of research, and are yet being extensively studied to help pave the path for a better translation and clinical application of EVs [25, 48, 61, 62].

EVs are involved in several biological interactions, such as intercellular communication, transportation of 


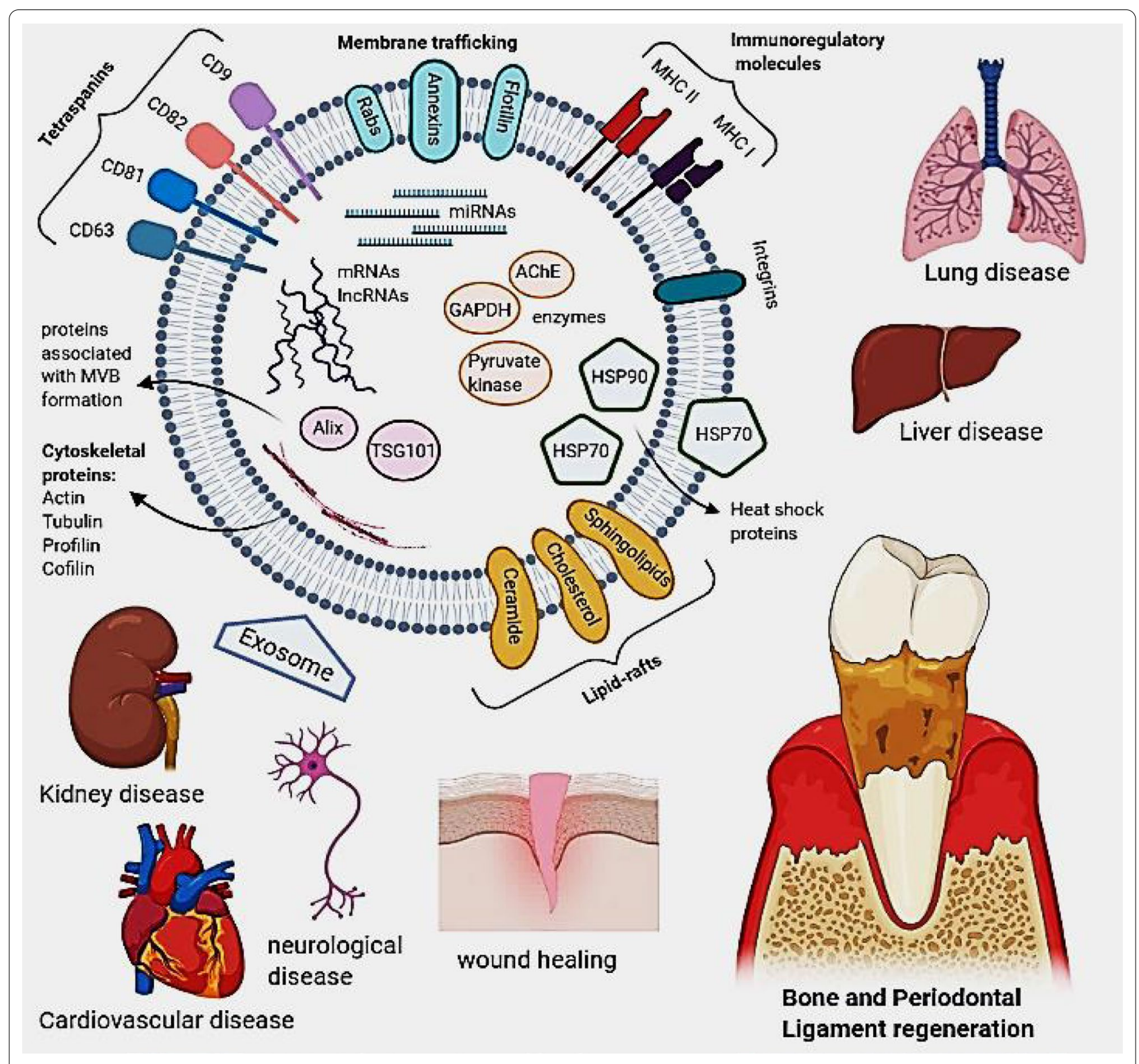

Fig. 2 Components and potential applications of extracellular vesicles

proteins and nucleic acids, tumorigenesis, and metabolism. They may also be used in diagnostic and therapeutic applications in various diseases, as host immune response modulators, and prions carriers [60, 63]. EVs membrane proteins may interact with cell surface and result in intercellular signaling. The mentioned process is done when a vesicles fuses with the target cell membrane via EVs surface proteins such as Alix or TSG101, and tetraspanins such as CD9, CD63, CD81, and CD82 [64, 65]. Also, internalization into a recipient cell may deliver cargo such as proteins and RNA that are active inside the recipient cell [66].
EVs have also been considered as therapeutic nano delivery systems as they have low immunogenicity, a long half-life in circulation, and are capable of penetrating through the brain-blood barrier [67-69]. EVs derived from stem/progenitor cells have the potential to mediate the regenerative responses of MSCs [70, 71]. As studies have revealed, secreted factors (also known as secretome) play a more critical role in tissue regeneration and repair than trans-differentiation capacity of cells [72]. EVs contents usually determine the changes within targeted cells. They have been proven to result in increased proliferation of cells via mitogen-activated protein kinase (MAPK) 
pathway [73, 74]. Pro-angiogenic properties of EVs from endothelial cells [75], endothelial progenitor cells [7678], and mesenchymal stem cells (MSCs) [79, 80] are established to be related to their miRNAs contents [75]. Moreover, due to the secretion of anti-inflammatory cytokines and facilitation of M2 macrophage formation, EVs have been identified as the one of the main sources of them $[81,82]$.

\section{Regenerative potential of stem cell derived extracellular vesicles}

Regenerative medicine involves the transplantation of stem cells into injured organs and tissues, and improving the regenerative potential and function of existing adult stem cells. In the last decades, numerous studies have confirmed the therapeutic potentials of the stem cells [83-85]. Direct usage of living stem cells is however still associated with some complications such as uncontrolled proliferation, tumorigenesis and metagenesis, teratoma formation, and graft-versus-host disease [30, 32]. Besides, the success rate of the treatment may be affected by improper handling methods, storage, and transportation [31]. Consequently, indirect mechanisms such as the application of paracrine secretions, growth factors, and cytokines have been considered as safer alternative treatments. Based on the ability of EVs to mimic stem cell properties, it is assumed that stem cell-derived EVs represent an appropriate therapeutic choice in regenerative medicine [86]. Compared to the direct use of stem cells, EVs could be generated on larger scales. They are smaller, easier to handle, and less expensive. They also have specific targets and have lower potential ethical and legal concerns [87]. These vesicles have high stability and can keep their potency in proper storage conditions for approximately 6 months [88, 89].

They also eliminate the risk of pulmonary embolism formation caused by cell transplantation [90]. EVs have been shown to be able to alter the recipient cells' functions by providing genetic information that affects their characteristics and paracrine factors and result in tissue regeneration [91]. The evidence has also revealed that the content of EVs is dynamic and largely depends on their cellular origin and physiological status, which needs to be taken into account when used as a therapeutic agent [27].

Another introduced means of application of these vesicles is use of CM in which stem cells were cultured. According to Osugi et al. [92], there are numerous growth factors such as IGF- 1 , VEGF, and TGF- $\beta 1$ in serum-free CM from human bone marrow-derived MSCs that can enhance bone regeneration. Positive anti-inflammatory and stimulatory effects on angiogenesis and periodontal and bone regeneration has been reported with application of EVs from stem cell CM [93-95].
Similar to stem cells, it has been observed that the source and origin from which EVs are obtained can change the results of their application. For example, dental pulp MSC-CM showed higher vasculogenesis in vivo and higher antiapoptotic, angiogenic, migration activity, and immunomodulatory effects in vitro in comparison with bone marrow MSC-CM. Human umbilical vein endothelial cells (HUVECs) shape more tube-like structures and cords when in touch with dental pulp MSC$\mathrm{CM}$, which is known to be the shape of endothelial cells [96]. PDL MSCs, as another dental source of stem cells, have shown a great potential for osseous regeneration [97, 98]. Qin et al. have reported that EVs derived from BMSCs can form more bony structures in the criticalsize calvaria bone defects than other cell types [99]. These difference should be considered along with the ease of access and isolation in future craniofacial regenerative studies [100].

\section{Clinical applications of EVs and their limitations}

The therapeutic effects of EVs have been illustrated in various fields, such as cardiovascular, neurological, lung, kidney, and liver diseases. Basu et al. have assessed the effect of current exosomal therapy on neuroregeneration and skin regeneration. They indicated that EVs are more stable and storable than cells. They decrease the risk of aneuploidy and immune rejection caused by in vivo allogeneic administration and might offer a substitutional therapy for different diseases [101].

There are shreds of evidence of EVs and even dental stem cell derived EVs are being successfully utilized in regeneration of other tissues and cure of disease such as the nervous and cardiovascular systems. A previous study reported that SHED-derived EVs are able to improve functional recovery after traumatic brain injury [102]. In addition, Alvarez-Ervitl et al. have shown the amelioration of Alzheimer's disease by the injection of EVs obtained from modified cells. Also, Ahmed et al. [103] demonstrated that DPSCs might act as a good source for secretome-based therapy of Alzheimer's disease. It has also been revealed that neurons secrete EVs containing alpha-synuclein and amyloid-beta protein that are, respectively, the indicators of the progression of Parkinson's and Alzheimer's diseases [104].

In myocardial infarction in a mouse model, ventricular remolding and the left ventricular ejection fraction were significantly improved after treatment with EVs. This improvement might have been the result of transporting the miR-29 family and IGF-1R from the EVs into the heart [104]. Lee et al. [105] showed that in hypoxiainduced pulmonary hypertension mice, EVs mediated the cytoprotective action of MSCs, which inhibited the disease progression and protected lung from adverse effects 
of hypertension. In another study, Zhou et al. [74] suggested that human MSC-derived EVs could be exploited as protection against apoptosis and cisplatin-induced renal oxidative stress in vivo and in vitro.

As mentioned, craniofacial regeneration is one of the growing fields of EV application. Furthermore, the therapeutic use of EVs has also gained attention in reconstructing the pulp complex and dentin in recent years. Ivica et al. [106] proposed that pulp-derived EVs, along with a fibrin gel, could be an effective combination for clinical translation on the way to improved cell-free regenerative endodontics. Furthermore, Huang et al. assessed the potential characteristics of EVs from dental pulp stem cells that were cultured in odontogenic differentiation conditions to promote odontogenic differentiation of DPSCs and hMSCs in vitro and in vivo. Their results highlighted the possible role of EVs as biomimetic tools to differentiate stem cells in a lineage-specific manner [107].

Although bone regeneration has been investigated in number of studies in recent years, there are only few available studies that are specifically focusing on EVs application in the regeneration of the tooth periodontium. The available evidence on EVs potential applications in bone and periodontal regenerations will be further discussed.

\section{Bone regeneration}

Bone regeneration via $\mathrm{EVs}$ or their $\mathrm{CM}$ has been the focus of many studies in recent years (Table 1). As previously mentioned, many researches have indicated that EVs have essential roles in cell-to-cell interaction, organto-organ communication and also, can be introduced as a novel signaling mediator in whole-body communications.

These naturally occurring nanoparticles include cargos such as genetic materials (mRNA, miRNAs and DNA), proteins and lipids that are able to change the function of targeted cells. If delivered to distinct cells via EVs, mRNAs and miRNAs can alter and regulate gene expression. Not only are EV required in cell-to-cell signaling, but abundant evidence propose that they play a key role in regenerative treatment through their maternal cargos or loaded materials.

There are four target fields in bone regeneration in which EVs have the potential to be utilized: angiogenesis, osteoblast proliferation, intercellular communications, and immunomodulation [108].

Blood vessels are the agents delivering minerals, growth factors, and progenitor cells to the area involved in regenerative activity and help sustain homeostasis. There is evidence suggesting possible angiogenic ability of EVs by improving vessel formation which may lead to stimulation of bone regeneration and growth [109]. It has been revealed that some types of EVs such as placental MSC-derived EVs stimulate endothelial cell proliferation, migration, and tube formation in vitro [110]. Furthermore, there are studies showing angiogenesis improvement in animal models due to EVs injection. Including injection of MSC-derived EVs, which reduced myocardial ischemic injury and improved angiogenesis in the ischemic heart [80].

It has been established that osteoblasts' primary function is bone formation by producing calcium and phosphate-based minerals. There are shreds of evidence on firming that EVs induce bone regeneration by direct regulation of osteoblast activity and proliferation [171]. Inder et al. [118] demonstrated that prostate cancer cellderived EVs regulated osteoblast proliferation by 1.5fold, showing excellent bone affinity. In another in vivo study, bone marrow stromal cell-derived EVs stimulated osteoblastic activity and resulted in an earlier rat calvaria defect healing [99].

EVs role in the bone metabolism is more recognized. For example, the differentiation of both osteoclasts and osteoblasts is activated by osteoclast precursors-derived EVs where osteoblast precursors-derived EVs induce osteoblastic activity [172]. Tan et al. have thoroughly investigated the available literature on bone regeneration using EVs from MCS finding positive therapeutic outcomes in a recent systematic review. They identified several factors influencing the potency of EVs and the outcomes of these regenerative treatments. These factors included the source of EVs, the anatomical origin and developmental age of the tissues for isolation of MSCs dosage/concentration of MSCEVs [173]. Several different bone defect and disease modules have been studied in EV bone regenerative methods with successful alleviation of the pathologic processes involved in bone injury/diseases through improvement of cell migration, survival, proliferation and osteogenic and angiogenic differentiation.

Understanding the underlying pathways of the effect of EV in bone formation has been also investigated. The study of signaling pathways displayed protein cargos of EVs involved in EVs biogenesis and production, internalization and several proteins implicated in osteogenesis. Proteomics analysis of MC3T3-EVs showed the high expression level of associated proteins with the eukaryotic initiation factor-2 pathway. These EVs proteins may have important role in osteoblast differentiation via BMP2. Cui et al., investigated MC3T3-E1 cells by microarray analysis and their findings showed mineralizing osteoblasts (MOBs) EVs contained 457 miRNAs, from which 43 had high expression levels, consisting of several "osteo-miRNAs"known to be expressed in osteoblasts (miR-1192, miR-680, and miR-302a). Analysis of miRNAs expression level in ST2 cells treated with MC3T3-E1 


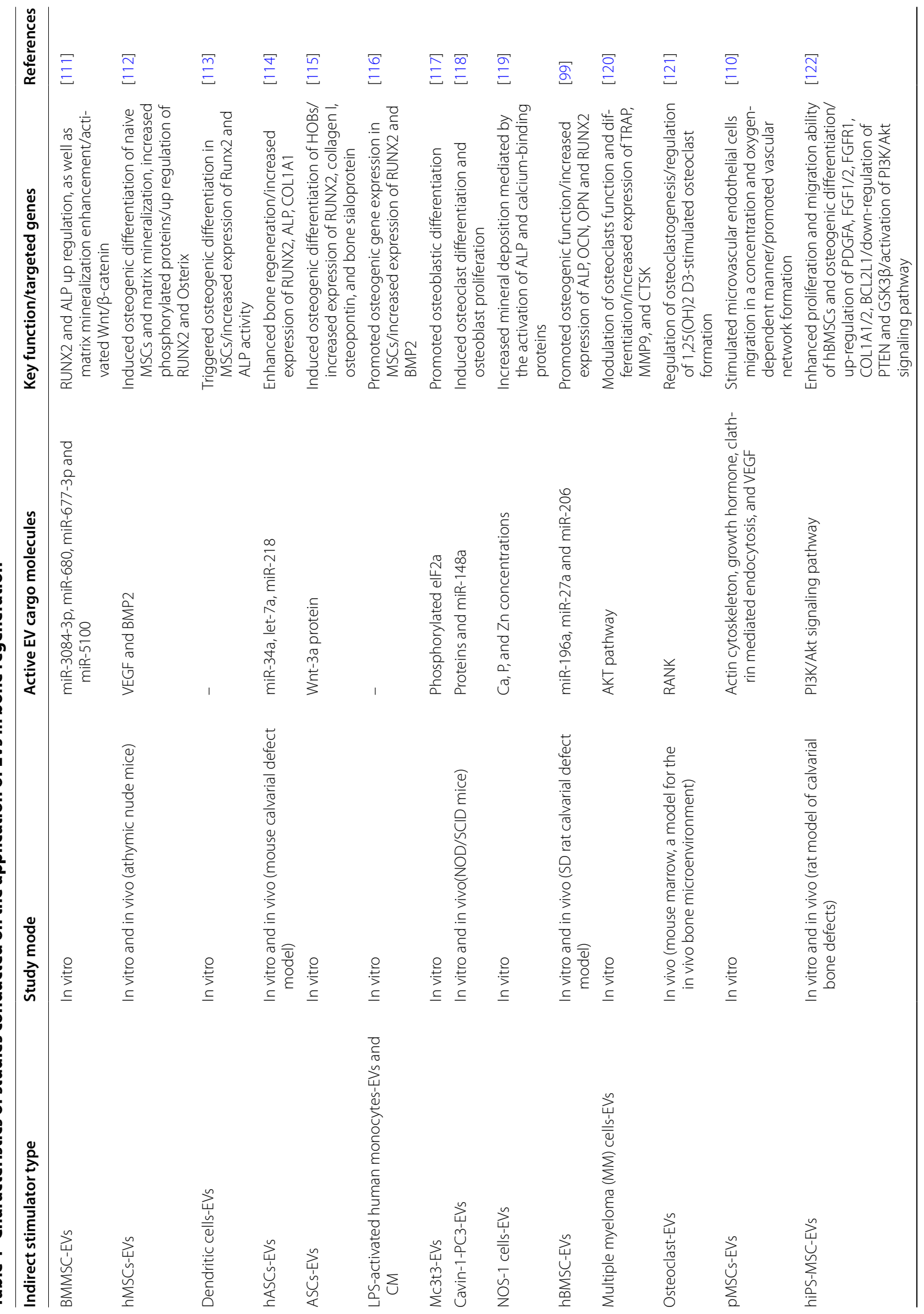




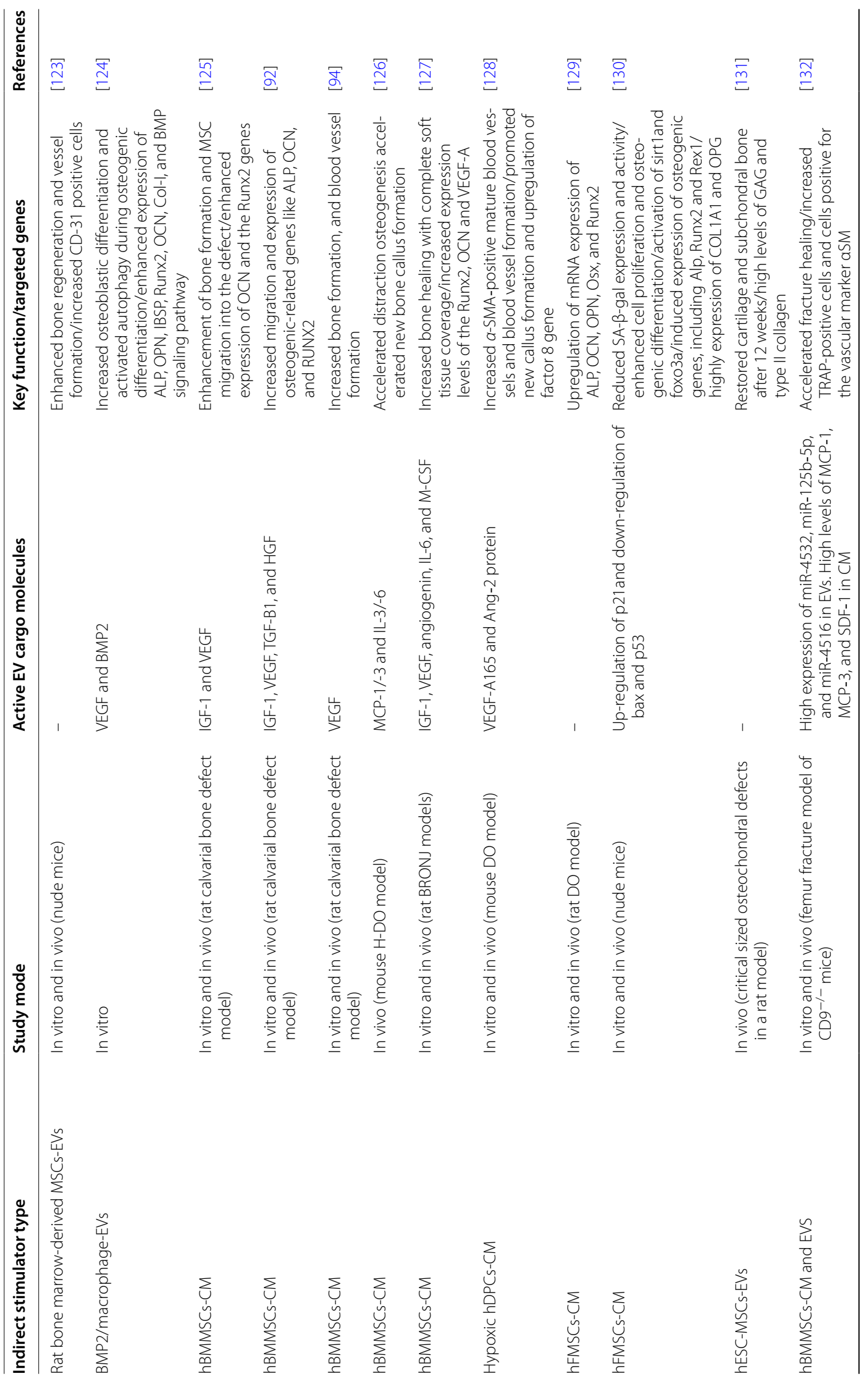




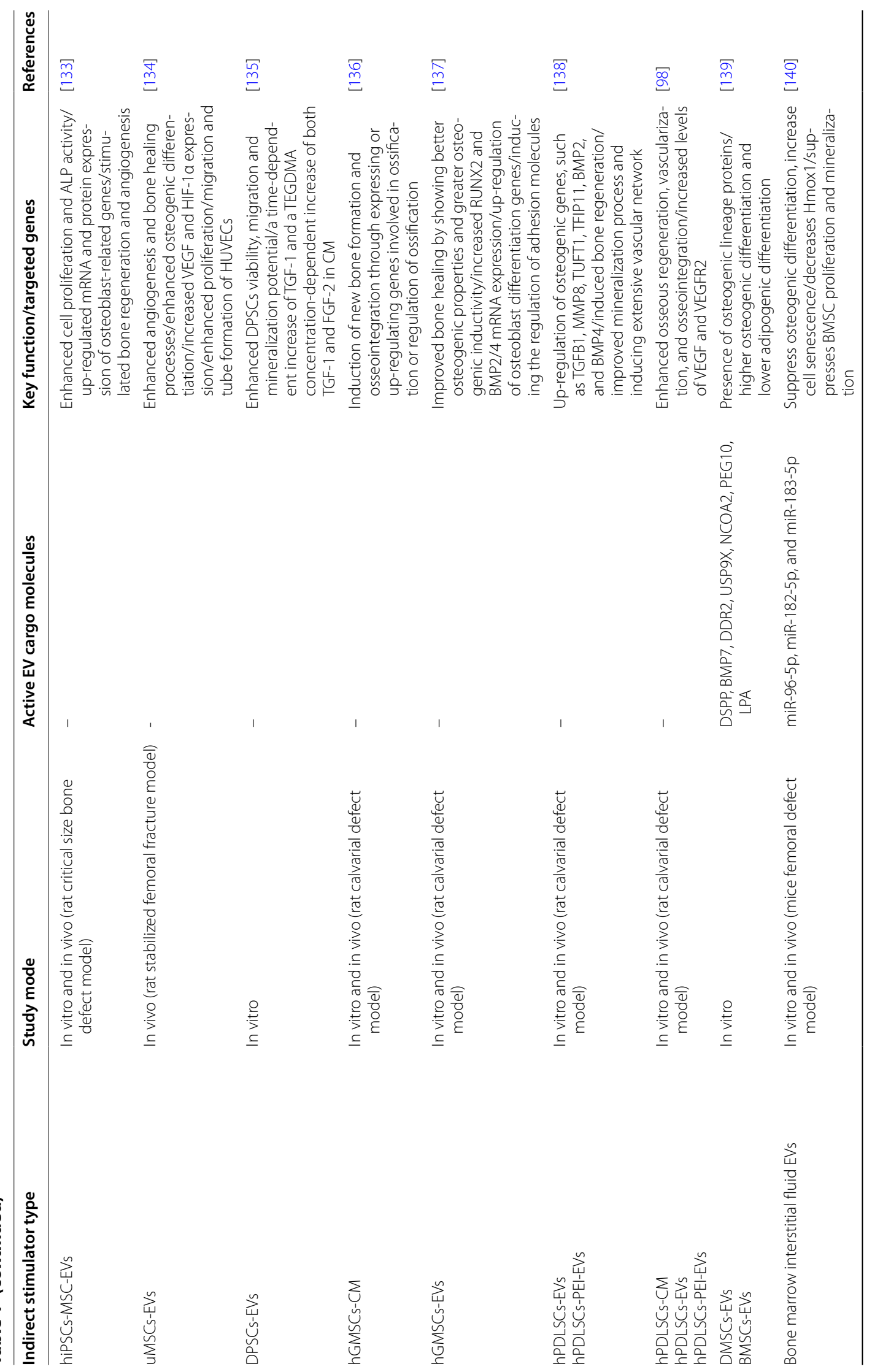




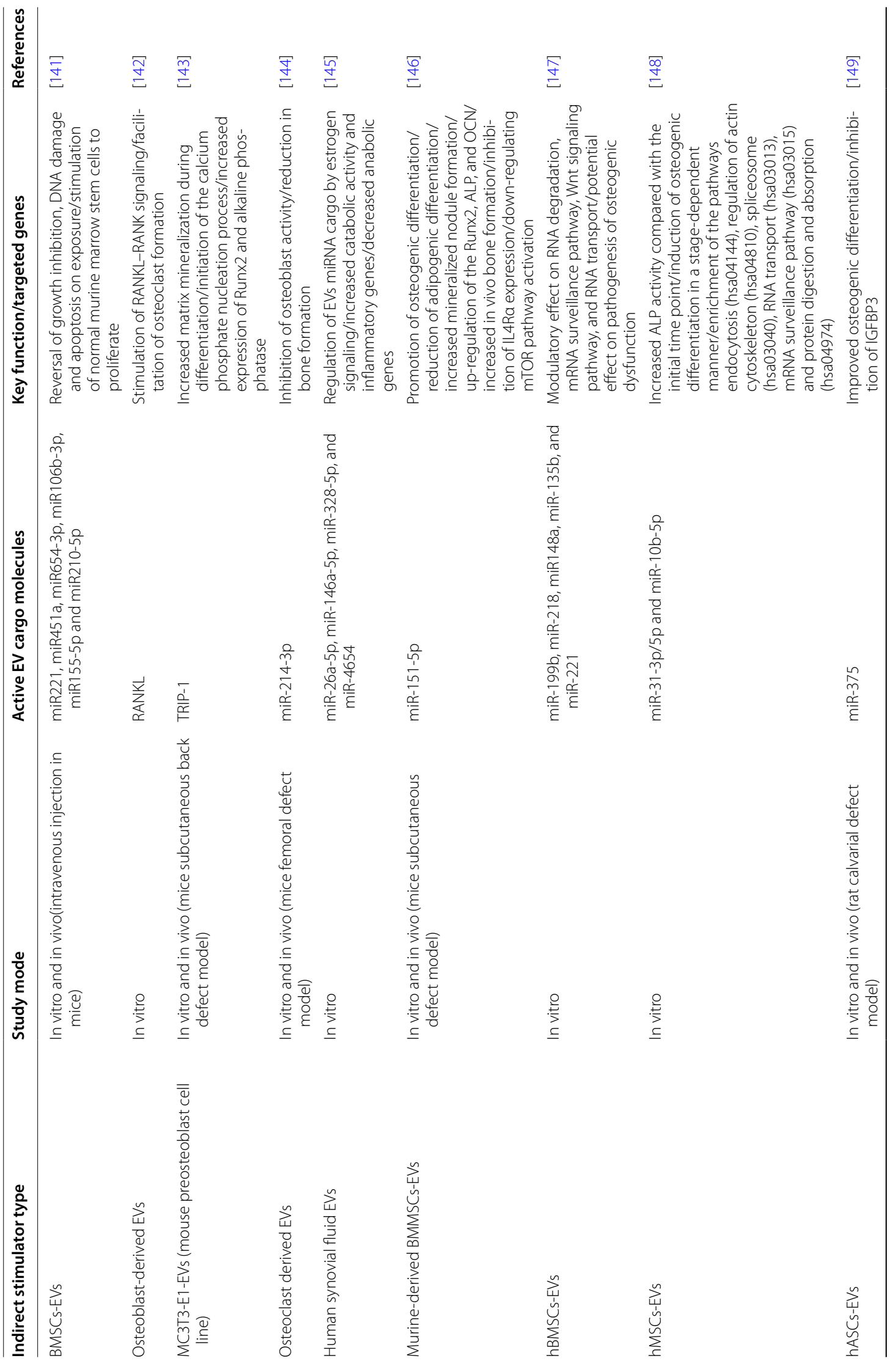


Gholami et al. Cell Biosci $\quad$ (2021) 11:16

Page 11 of 21

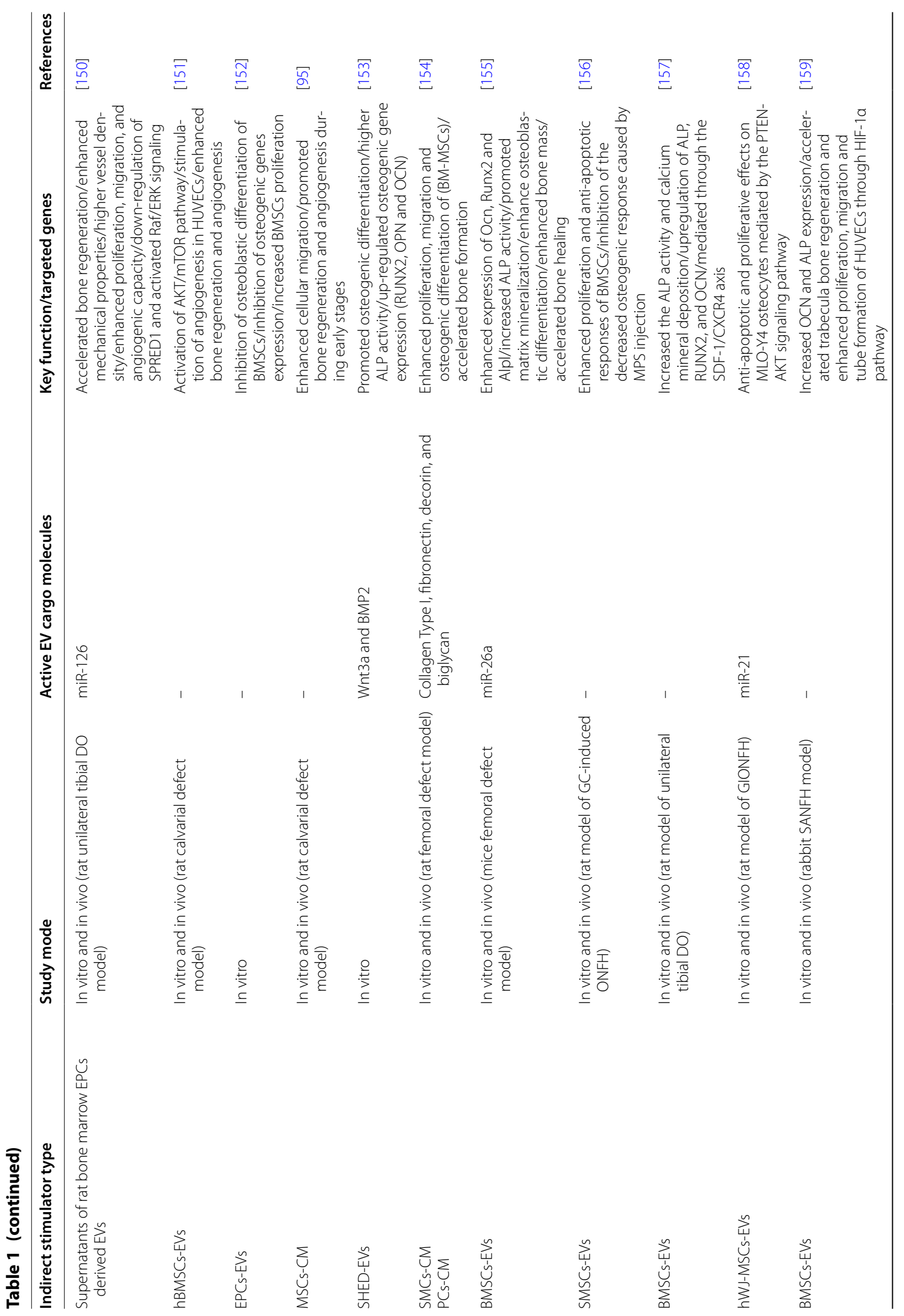




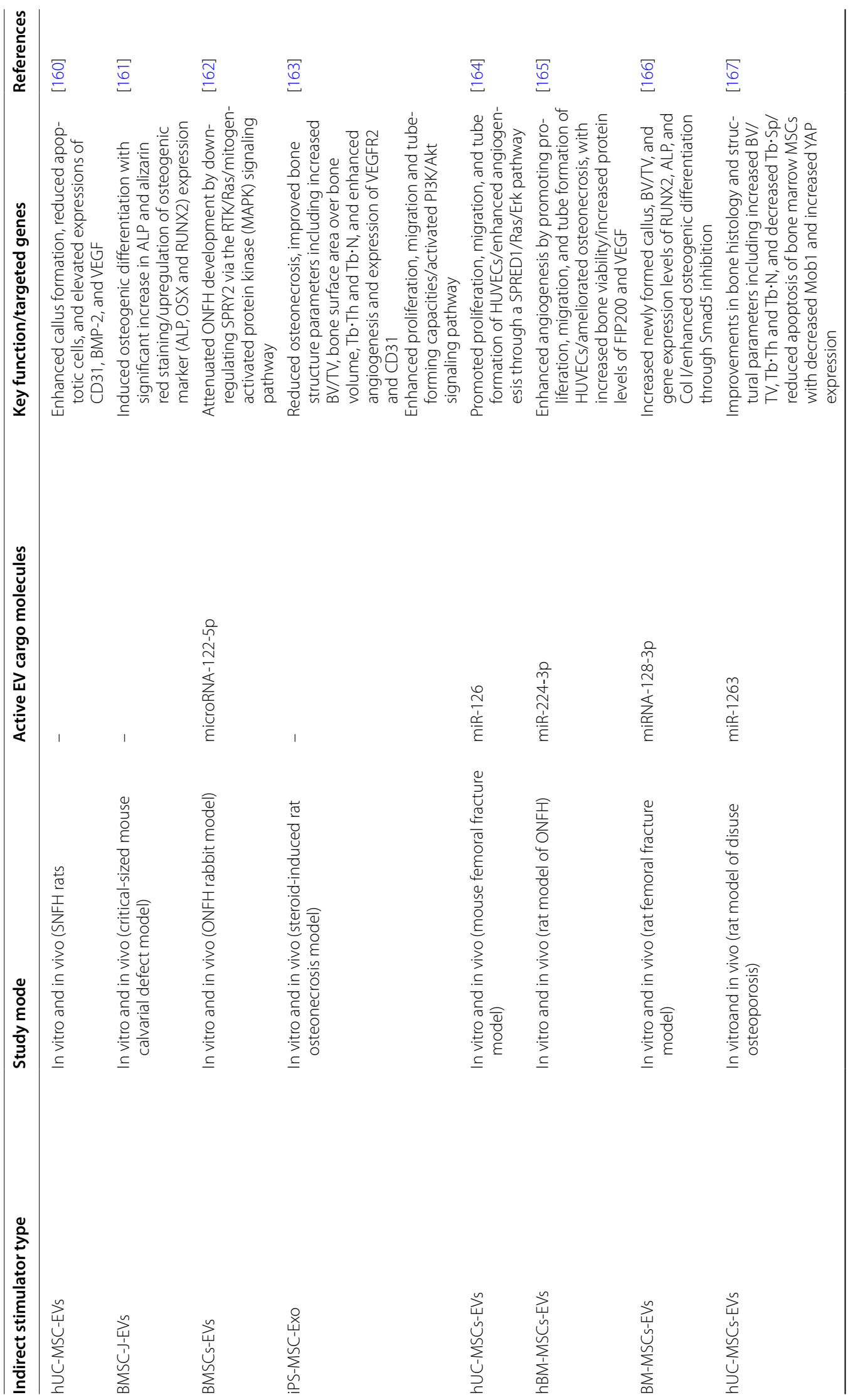




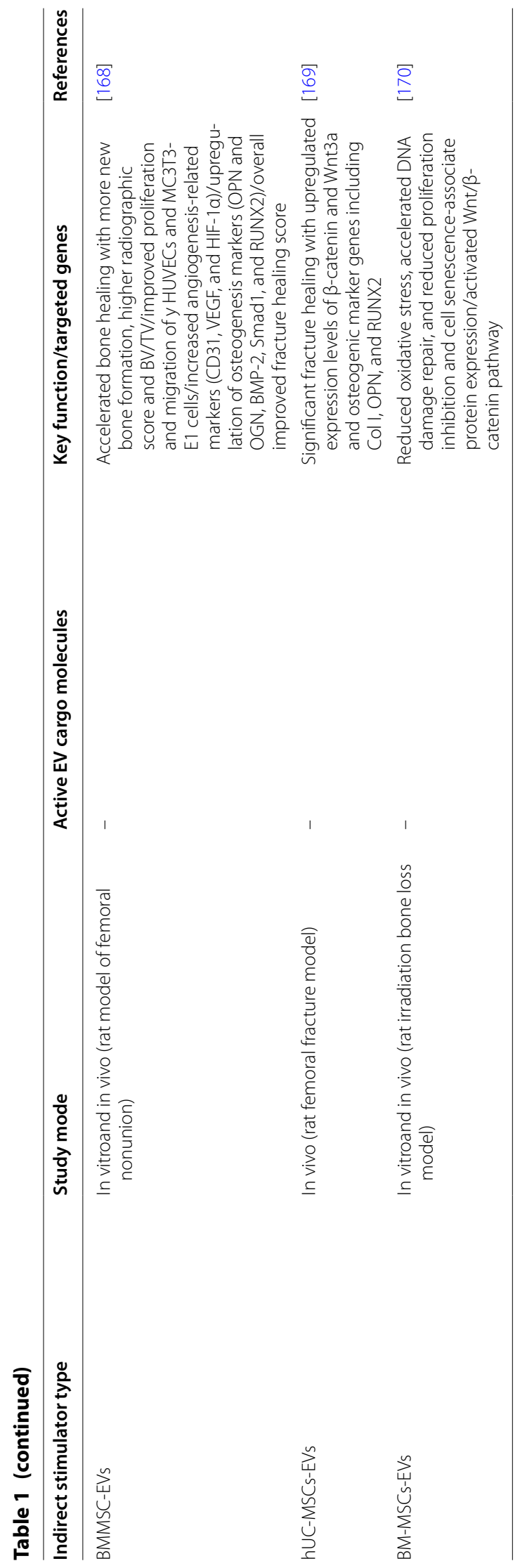


derived EVs detected 91 upregulated (including miR3084-3p, miR-680, miR-677-3p, and miR-5100) and 182 downregulated miRNAs which cross-talked through the $\beta$-catenin gene as a valuable transcription factor in osteoblast differentiation [121, 142].

EV-based intercellular communication between osteoblasts and osteoclasts may be considered as a novel regulator of bone remodeling. Osteoblasts release RANKL containing EVs, which are transferred to osteoclast precursors. It also facilitates osteoclast formation by stimulation of RANKL-RANK signaling. The studies also established the EVs application as a pro-osteogenic approach in bone regenerative field. In addition to their osteogeniccapacity, RANKL protein of UAMS-32P stro$\mathrm{mal} /$ osteoblastic cell line-EVs can regulate formation of osteoclast cells [121, 142].

Qin et al. [99] showed that miR-196a is the key factor in the regulation of osteoblastic differentiation and the expression of osteogenic genes. Cui et al. [121] have reported that the EVs from mineralizing osteoblasts are capable of entering into ST2 recipient cells in vitro and induce osteoblastic differentiation via the Wnt signaling pathway by affecting Axin 1 and $\beta$ catenin expression. According to the study by $\mathrm{Li}$ et al. aging can change bone metabolism and interfere with it. They showed that miR214-3p, as a cargo of EVs secreted from osteoclasts, could be associated with less osteoblastic bone formation in elderly patients [144].

Furthermore, some studies have applied EVs through new techniques. For example, Diomede et al. used a three-dimensional printed PLA scaffold and human gingival stem cell-derived EVsto promote bone healing in rat calvaria bone defect [137]. Meanwhile, Zhang et al. showed that EVs combining tricalcium phosphate-modified scaffolds caused an increased osteogenic differentiation in vitro. They also reported promoted osteogenesis in rat calvarial bone defects induced by activating the PI3K/Akt signaling pathway [99]. Together, controlling intercellular communications and signaling pathways by EVs gives us the opportunity of regulating bone metabolism and mineralization.

The mechanisms by which EVs modulate immune system are not yet completely understood; however, they may have the potential to be used as a tolerant therapeutic agent in bone regeneration in immune-competent animals [108]. Ji et al. [174] have demonstrated that DPSC-derived EVs are a potential option that may regulate immune responses. Both immune cells and nonimmune cells have the ability to produce EVs to regulate immunity. Antigen-presenting and tumor-derived EVs are the most frequently mentioned immunological EVs. Tumor-derived EVs inhibit macrophage maturation associated with TGF- $\beta$. Many researchers have also focused on EVs' function in inflammation. For example, Ismail et al. [175] reported macrophage-derived EVs enveloping miR-223 regulated macrophage differentiation. As we know, M2 macrophages play an important role in tissue and bone regeneration [176]. Tumor-derived EVs, by contrast, inhibit macrophage maturation associated with TGF- $\beta$ [177]. Generally, modulation of innate or adaptive immunity by EVs is a potential target for clinical therapeutics in bone regeneration.

\section{Periodontal regeneration}

Routine periodontal treatments can successfully reduce the number of pathogens in a periodontal defect; however, a predictable treatment procedure for reconstructing the lost structures has not been found yet [1]. Some evidence support that MSC-derived EVs can be useful in promoting periodontal ligaments regeneration. As noted, the secretomes of MSCs are known to be responsible for their regenerative effects, containing proteins, lipids, nucleic acid, and trophic factors as growth factors, chemokines, cytokines, hormones, and EVs. Therefore, many studies have started using EVs or their CM as cellfree techniques in periodontal regeneration. Different sources and delivery routes have been used for this purpose (Table 2).

Most studies on periodontal regeneration have utilized MSCs CM reporting positive outcomes. Kawai et al. [181] have used Human bone marrow MSCs-CM and reported that it may lead to the enhancement of periodontal tissue regeneration by stimulating angiogenesis and even the mobilization of endogenous MSCs.

Among different sources of MSCs, periodontal ligament stem cells (PDLSCs) are the most commonly studied and potentially considered the most suitable source for periodontal regeneration [183, 184]. They are easily accessible and capable of secreting mineralized structures and can be the best choice for periodontal regeneration due their similar origin. PDLSCs carried by hydroxyapatite/tricalcium phosphate (HA/TCP) were shown to be able to form a cementum/PDL-like structure in vivo [183]. Transplantation of PDLSC-CM has been investigated in some studies and demonstrated considerable new PDL attachment and bone defect regeneration. Nagata et al. investigated the regenerative potential of conditioned mediums (CMs) acquired from cultured periodontal ligament stem cells (PDLSCs) on regenerating periodontal defects models in rats. Their results suggested improved periodontal regeneration and reported a suppression of the inflammatory response caused by TNF- $\alpha$ production as a result of this treatment method [93]. Qiu et al. explored the periodontal tissue regeneration by conditioned media from gingival mesenchymal stem cells (GMSCs) or PDLSCs in rat periodontal 
Table 2 Characteristics of studies conducted on the application of EVs for periodontal regeneration

\begin{tabular}{|c|c|c|c|c|}
\hline Origin/source & Study mode & Active EV cargo molecules & Key function/targeted genes & References \\
\hline MSCs-EVs & $\begin{array}{l}\text { In vitro and in vivo (rat periodontal } \\
\text { defect model) }\end{array}$ & - & $\begin{array}{l}\text { Improved periodontal ligament } \\
\text { function and promoted regenera- } \\
\text { tion/initiation of prosurvival AKT } \\
\text { and ERK signaling in PDL cells/ } \\
\text { enhanced cell viability }\end{array}$ & [178] \\
\hline ADSCs-EVs & In vivo (rat ligature model) & - & $\begin{array}{l}\text { Improved periodontal repair and } \\
\text { regeneration }\end{array}$ & {$[179]$} \\
\hline Mobilized-DPSCs-CM & In vitro & - & $\begin{array}{l}\text { Greater proliferation and migratory } \\
\text { activity of NIH3T3 cells/higher } \\
\text { immunomodulatory effects/ } \\
\text { decreased apoptosis }\end{array}$ & {$[180]$} \\
\hline PDLSCs-CM & In vivo (rat periodontal defect model) & $\begin{array}{l}\text { SerpinE1, MCP-1, TIMP-1, uPA, VEGF, } \\
\text { IGFBP6, IGFBP2, PDGFR- } \beta \text {, and } \\
\text { IFN-y }\end{array}$ & $\begin{array}{l}\text { Enhanced periodontal regeneration } \\
\text { by suppressing the inflammatory } \\
\text { response via decrease in TNF-a }\end{array}$ & {$[93]$} \\
\hline MSCs-CM & $\begin{array}{l}\text { In vitro and in vivo (rat periodontal } \\
\text { defect model) }\end{array}$ & IGF-1, VEGF, TGF- $\beta 1$, HGF & $\begin{array}{l}\text { Increased wound-healing and } \\
\text { angiogenesis/up-regulation of } \\
\text { osteogenetic- and angiogenic- } \\
\text { related genes expression/induced } \\
\text { periodontal tissue regeneration }\end{array}$ & {$[181]$} \\
\hline $\begin{array}{l}\text { GMSCs-CM } \\
\text { PDLSCs-CM }\end{array}$ & $\begin{array}{l}\text { In vitro and in vivo (rat periodontal } \\
\text { defect model) }\end{array}$ & - & $\begin{array}{l}\text { Promoted periodontal defect } \\
\text { regeneration/lower expression } \\
\text { levels of TNF- } a \text { and IL-1 } 1 \beta / \text { higher } \\
\text { IL-10 expression/higher expression } \\
\text { levels of BSP-II and Runx2 }\end{array}$ & [182] \\
\hline
\end{tabular}

defects. Their results showed that similar to PDLSC-CM, GMSC-CM transplantation significantly promoted periodontal defect regeneration in rats. They expressed that this resulted from the regulation of inflammation by MSC-CM and also the facilitation of osteogenic differentiation of bone progenitor cells in the wound region.

EVs isolated from adipose-derived stem cells were used by Mohammed et al. as supplementary treatment to the non-surgical periodontal therapy. They divided 50 rats with ligature-induced periodontitis into four groups, including control, SRP, ADSCs, and exosome group. EVs were locally injected through the pockets by using a plastic syringe after doing a scaling and root planning. They evaluated the progress at different intervals, and the EVs treated group showed the best result with a significantly higher area percentage of newly formed tissues [179].

Chew et al. have also applied EVs derived from hMSCs in regeneration of surgically created periodontal defect in a rat model. They reported that single implantation of collagen sponges has the potential to elevate periodontal regeneration by increasing bone construction and enhancing functional PDL length. They suggested that this could be related to adenosine receptor activation of AKT and ERK signaling pathways, promoting proliferation and migration of PDL cells [178]. MSC-derived EVs have also documented to be able to enhance the repair of osteochondral defects through a reduction in proinflammatory cytokines and an increase in regenerative
M2 macrophage counts [185]. Since the activation of pathways that cause bone loss requires an adequate amount of inflammatory factors concentration, the antiinflammatory characteristic of MSC-derived EVs gained noticeable attention for periodontal regeneration applications [186]. The available evidence indicates that EV based therapies are of valuable therapeutic approaches and have the potential of increasing the success of periodontal regenerative therapies [182]. Further research is still necessary in order to find ideal and standardized sources of EVs, their effective concentration, frequency of treatment and suitable scaffolds or delivery routes used for efficient regeneration of the complex structure of periodontal tissue and further develop their therapeutic applications in this field.

\section{Future landscapes of EVs applications}

Many studies have focused on biomedical EVs applications. Based on their physical functions, EVs of particular cell types have been used as therapeutic mediators in immune therapy, drug delivery, vaccination trials, and regenerative medicine. For example, Xu et al. [187] highlighted the utility of EVs for the development of cancer diagnostics and therapeutics. Mianehsaz et al. [188] reviewed the evidence for EVs from MSCs as a new cellfree therapy method osteoarthritis and joint damage. Synthetic EVs, tunable EVs, and EVs mimetics, as well as EVs designed to overexpress or knockdown signaling 
pathways associated with pathological conditions, are considered as the next generation of EVs-based products to be studied and developed which may have potential applications in oral and craniofacial diseases [101].

Adequate standards for EVs isolation, manipulation, and characterization need to be defined to reach future progression in the clinical application of EVs. Factors such as the distribution, cargoes, and the purification protocols can manipulate EVs effects [63]. Since EV cargoes depend significantly on their origins, it is essential to profile EVs before clinical applications [189]. There are two commonly used purification procedures, which exploit either repeated ultracentrifugation or ultrafiltration. These techniques provide only a low EVs yield and take a relatively long time. For instance, $5 \times 10^{6}$ myeloma cells can deliver only 5-6 $\mu$ g of EVs $[190,191]$. Achieving good manufacturing practices requires development in EVs isolation techniques. Therefore, developments in EVs studies highly rely on finding novel methods to efficiently isolate them.

It should be noted that delivering EVs in therapeutic dosage to target cells, particularly via systemic injection, may not always be as simple as it looks. Riau et al. proposed the possibility of using the encapsulated form of EVs with biodegradable or highly porous hydrogels. Approaches to encapsulate nanoparticles, like EVs, and instances of possible materials for sustained delivery of the EVs from the stem cells are also main areas of focuses in several studies [192].

After injection, EVs are distributed mostly in the bone, lung, spleen, liver, and kidney. Therefore, it is necessary to assess the clearance and final dosage in the organs [193]. It is still imprecise how to end the biological effects of EVs when the satisfactory outcome is accomplished. Moreover, the half time of EVs applied should be considered to be long enough for achieving the therapeutic aim. Thus, examining EVs in pre-clinical models before moving on to the clinical phase is crucial for their correct translational applications.

\section{Conclusion and prospects}

Several recent studies have been exploring the application of EVs in regenerative medicine. According to these studies, EVs have the potential of regulating immune microenvironment, promoting vascularization, facilitating osteoblasts activity, proliferation and mineralization. Significant development has been made to explore EVs biology, structure, and contents as well as understanding the exact mechanisms by which EVs may alter target cells functions. It is well established that the source of stem cells and their culture conditions affect the functional properties of the secreted EVs. EV-based therapies are considered as novel free-cell therapy approach which is easier to handle and reduces the risk of tumorigenesis, host rejection, and infections associated with direct cell therapy. The available research indicates a great potential for EV application for improvement in success and predictability of bone and periodontal tissue regeneration therapies.

However, we are still facing challenges for ideal clinical application of EVs and further investigations are needed to achieve a protocol for efficient engineering of these nano-bioparticles to maintain exact composition and structure of isolated EVs.

\section{Acknowledgements \\ The authors gratefully acknowledge the support from Hamadan University of Medical Sciences (Grant number: 9910026692), Iran. The figures were designed in biorenderer.com.}

\section{Authors' contributions}

LG, KK and VTN analyzed, interpreted, and provided major contributions in writing the manuscript. SS, MSJ and ZA contributed in writing the manuscript. $L G, K K$ and RT edit the final version. All authors read and approved the final manuscript.

\section{Funding}

This paper was supported as part of a project funded by Hamadan University of Medical Sciences (Grant number: 9910026692).

\section{Availability of data and materials}

The datasets generated and analyzed during the current study are available from the corresponding authors on reasonable request by permission of institute and department chairman's.

Ethics approval and consent to participate

Not applicable.

\section{Consent for publication}

Not applicable.

\section{Competing interests}

The authors declare that they have no competing interests.

\section{Author details}

${ }^{1}$ Department of Periodontics, Dental Research Center, Hamadan University of Medical Sciences, Hamadan, Iran. ${ }^{2}$ Department of Tissue Engineering and Applied Cell Sciences, School of Medicine, Semnan University of Medical Science, Semnan, Iran. ${ }^{3}$ Nervous System Stem Cells Research Center, Semnan University of Medical Sciences, Semnan, Iran. ${ }^{4}$ Student Research Committee, School of Dentistry, Hamadan University of Medical Sciences, Hamadan, Iran. ${ }^{5}$ Department of Oral Biological and Medical Sciences, Faculty of Dentistry, The University of British Columbia, Vancouver, Canada. ${ }^{6}$ Brain and Spinal Cord Injury Research Center, Neuroscience Institute, Tehran University of Medical Science, Tehran, Iran. ${ }^{7}$ Department of Tissue Engineering and Applied Cell Sciences, School of Advanced Technologies in Medicine, Tehran University of Medical Sciences, Tehran, Iran. ${ }^{8}$ Department of Photodynamic, Medical Laser Research Center, Yara Institute, ACECR, Tehran, Iran.

Received: 2 November 2020 Accepted: 31 December 2020

Published online: 12 January 2021

\footnotetext{
References

1. Kassebaum NJ, Smith AGC, Bernabé E, Fleming TD, Reynolds AE, Vos T, et al. Global, regional, and national prevalence, incidence, and disability-adjusted life years for oral conditions for 195 countries, 1990-2015: a systematic analysis for the global burden of diseases, injuries, and risk
} 
factors. J Dent Res. 2017;96:380-7. https://doi.org/10.1177/0022034517 693566.

2. Heitz-Mayfield LJA, Lang NP. Surgical and nonsurgical periodontal therapy. Learned and unlearned concepts. Periodontol 2000. 2013;62:218-31.

3. Villar CC, Cochran DL. Regeneration of periodontal tissues: guided tissue regeneration. Dent Clin. 2010;54:73-92.

4. Gantes B, Martin M, Garrett S, Egelberg J. Treatment of periodontal furcation defects: (II) bone regeneration in mandibular class II defects. J Clin Periodontol. 1988;15:232-9.

5. Anitua E, Troya M, Orive G. An autologous platelet-rich plasma stimulates periodontal ligament regeneration. J Periodontol. 2013;84:1556-66.

6. Lynch SE, Williams RC, Poison AM, Howell TH, Reddy MS, Zappa UE, et al. A combination of platelet-derived and insulin-like growth factors enhances periodontal regeneration. J Clin Periodontol. 1989;16:545-8.

7. Nevins M, Giannobile WV, McGuire MK, Kao RT, Mellonig JT, Hinrichs $\mathrm{JE}$, et al. Platelet-derived growth factor stimulates bone fill and rate of attachment level gain: results of a large multicenter randomized controlled trial. J Periodontol. 2005;76:2205-15.

8. Kassebaum NJ, Bernabé E, Dahiya M, Bhandari B, Murray CJL, Marcenes W. Global burden of severe periodontitis in 1990-2010: a systematic review and meta-regression. J Dent Res. 2014;93:1045-53.

9. Almubarak S, Nethercott H, Freeberg M, Beaudon C, Jha A, Jackson W, et al. Tissue engineering strategies for promoting vascularized bone regeneration. Bone. 2016;83:197-209.

10. Chehade MJ, Bachorski A. Development of the Australian core competencies in musculoskeletal basic and clinical science project-phase 1. Med J Aust. 2008;189:162-5.

11. Rezwan K, Chen QZ, Blaker JJ, Boccaccini AR. Biodegradable and bioactive porous polymer/inorganic composite scaffolds for bone tissue engineering. Biomaterials. 2006;27:3413-31.

12. Yang K, Zhang J, Ma X, Ma Y, Kan C, Ma H, et al. \$ $\$$-tricalcium phosphate/poly (glycerol sebacate) scaffolds with robust mechanical property for bone tissue engineering. Mater Sci Eng C. 2015;56:37-47.

13. Kolambkar YM, Boerckel JD, Dupont KM, Bajin M, Huebsch N, Mooney $\mathrm{DJ}$, et al. Spatiotemporal delivery of bone morphogenetic protein enhances functional repair of segmental bone defects. Bone. 2011:49:485-92.

14. Medvedeva EV, Grebenik EA, Gornostaeva SN, Telpuhov VI, Lychagin AV, Timashev PS, et al. Repair of damaged articular cartilage: current approaches and future directions. Int J Mol Sci. 2018;19:2366.

15. Mankin HJ, Hornicek FJ, Raskin KA. Infection in massive bone allografts. Clin Orthop Relat Res. 2005;432:210-6.

16. Sorger Jl, Hornicek FJ, Zavatta M, Menzner JP, Gebhardt MC, Tomford WW, et al. Allograft fractures revisited. Clin Orthop Relat Res. 2001;382:66-74.

17. Dinopoulos H, Dimitriou R, Giannoudis PV. Bone graft substitutes. RETRACTED: what are the options? Amsterdam: Elsevier; 2012.

18. Lee W-C, Guntur AR, Long F, Rosen CJ. Energy metabolism of the osteoblast: implications for osteoporosis. Endocr Rev. 2017;38:255-66.

19. Park Y-E, Musson DS, Naot D, Cornish J. Cell-cell communication in bone development and whole-body homeostasis and pharmacological avenues for bone disorders. Curr Opin Pharmacol. 2017;34:21-35.

20. Mao AS, Mooney DJ. Regenerative medicine: current therapies and future directions. Proc Natl Acad Sci USA. 2015;112:14452-9.

21. Caplan Al. Adult mesenchymal stem cells for tissue engineering versus regenerative medicine. J Cell Physiol. 2007;213:341-7.

22. Nooshabadi VT, Mardpour S, Yousefi-Ahmadipour A, Allahverdi A, Izadpanah M, Daneshimehr F, et al. The extracellular vesicles-derived from mesenchymal stromal cells: a new therapeutic option in regenerative medicine. J Cell Biochem. 2018;1 19:8048-73. https://doi.org/10.1002/ jcb.26726.

23. Gronthos S, Mankani M, Brahim J, Robey PG, Shi S. Postnatal human dental pulp stem cells (DPSCs) in vitro and in vivo. Proc Natl Acad Sci. 2000;97:13625-30.

24. Khoshhal M, Amiri I, Gholami L. Comparison of in vitro properties of periodontal ligament stem cells derived from permanent and deciduous teeth. J Dent Res Dent Clin Dent Prospects. 2017;11:140-8.

25. Théry C, Witwer KW, Aikawa E, Alcaraz MJ, Anderson JD, Andriantsitohaina $\mathrm{R}$, et al. Minimal information for studies of extracellular vesicles
2018 (MISEV2018): a position statement of the International Society for Extracellular Vesicles and update of the MISEV2014 guidelines. J Extracell Vesicles. 2018;7:1535750. https://doi.org/10.1080/20013 078.2018.1535750.

26. Bakkar M, Liu Y, Fang D, Stegen C, Su X, Ramamoorthi M, et al. A simplified and systematic method to isolate, culture, and characterize multiple types of human dental stem cells from a single tooth. In: Adult stem cells. New York: Springer; 2017. p. 191-207.

27. Raposo G, Stoorvogel W. Extracellular vesicles: exosomes, microvesicles, and friends. J Cell Biol. 2013;200:373-83.

28. Yáñez-Mó M, Siljander PR-M, Andreu Z, Bedina Zavec A, Borràs FE, Buzas El, et al. Biological properties of extracellular vesicles and their physiological functions. J Extracell Vesicles. 2015:4:27066.

29. Einabadi M, Ai J, Kargar M, Kafilzadeh F, Taghdiri Nooshabadi V, Jamali $H$. Mesenchymal cell-derived exosomes as novel useful candidates for drug delivery. Arch Neurosci. 2020;7:e98722.

30. Erdö F, Bührle C, Blunk J, Hoehn M, Xia Y, Fleischmann B, et al. Hostdependent tumorigenesis of embryonic stem cell transplantation in experimental stroke. J Cereb Blood Flow Metab. 2003;23:780-5.

31. Herberts CA, Kwa MSG, Hermsen HPH. Risk factors in the development of stem cell therapy. J Transl Med. 2011;9:29.

32. Volarevic V, Markovic BS, Gazdic M, Volarevic A, Jovicic N, Arsenijevic N, et al. Ethical and safety issues of stem cell-based therapy. Int J Med Sci. 2018;15:36.

33. Taghdiri Nooshabadi V, Verdi J, Ebrahimi-Barough S, Mowla J, Atlasi MA, Mazoochi T, et al. Endometrial mesenchymal stem cell-derived exosome promote endothelial cell angiogenesis in a dose dependent manner: a new perspective on regenerative medicine and cell-free therapy. Arch Neurosci. 2019;6:e94041.

34. Bermudez MA, Sendon-Lago J, Eiro N, Trevino M, Gonzalez F, YebraPimentel $\mathrm{E}$, et al. Corneal epithelial wound healing and bactericidal effect of conditioned medium from human uterine cervical stem cells. Invest Ophthalmol Vis Sci. 2015;56:983-92.

35. Kowal J, Tkach M, Théry C. Biogenesis and secretion of exosomes. Curr Opin Cell Biol. 2014;29:116-25.

36. Witwer KW, Van Balkom BWM, Bruno S, Choo A, Dominici M, Gimona $M$, et al. Defining mesenchymal stromal cell (MSC)-derived small extracellular vesicles for therapeutic applications. J Extracell Vesicles. 2019;8:1609206. https://doi.org/10.1080/20013078.2019.1609206.

37. Trams EG, Lauter CJ, Salem JN, Heine U. Exfoliation of membrane ectoenzymes in the form of micro-vesicles. Biochim Biophys Acta (BBA). 1981;645:63-70.

38. Keller S, Ridinger J, Rupp A-K, Janssen JWG, Altevogt P. Body fluid derived exosomes as a novel template for clinical diagnostics. J Transl Med. 2011;9:86.

39. Lässer C, Alikhani VS, Ekström K, Eldh M, Paredes PT, Bossios A, et al. Human saliva, plasma and breast milk exosomes contain RNA: uptake by macrophages. J TransI Med. 2011;9:9.

40. Conde-Vancells J, Rodriguez-Suarez E, Embade N, Gil D, Matthiesen R, Valle $M$, et al. Characterization and comprehensive proteome profiling of exosomes secreted by hepatocytes. J Proteome Res. 2008;7:5157-66.

41. Subra C, Grand D, Laulagnier K, Stella A, Lambeau G, Paillasse M, et al. Exosomes account for vesicle-mediated transcellular transport of activatable phospholipases and prostaglandins. J Lipid Res. 2010;51:2105-20.

42. Baglio SR, Rooijers K, Koppers-Lalic D, Verweij FJ, Lanzón MP, Zini N, et al. Human bone marrow-and adipose-mesenchymal stem cells secrete exosomes enriched in distinctive miRNA and tRNA species. Stem Cell Res Ther. 2015;6:127.

43. Mathivanan S, Simpson RJ. ExoCarta. A compendium of exosomal proteins and RNA. Proteomics. 2009;9:4997-5000.

44. Subra C, Laulagnier K, Perret B, Record M. Exosome lipidomics unravels lipid sorting at the level of multivesicular bodies. Biochimie. 2007:89:205-12.

45. Trajkovic K, Hsu C, Chiantia S, Rajendran L, Wenzel D, Wieland F, et al. Ceramide triggers budding of exosome vesicles into multivesicular endosomes. Science. 2008;319:1244-7.

46. Wubbolts R, Leckie RS, Veenhuizen PTM, Schwarzmann G, Möbius W, Hoernschemeyer J, et al. Proteomic and biochemical analyses of human B cell-derived exosomes potential implications for their function and multivesicular body formation. J Biol Chem. 2003;278:10963-72. 
47. Villarroya-Beltri C, Gutiérrez-Vázquez C, Sánchez-Cabo F, Pérez-Hernández D, Vázquez J, Martin-Cofreces N, et al. Sumoylated hnRNPA2B1 controls the sorting of miRNAs into exosomes through binding to specific motifs. Nat Commun. 2013;4:2980.

48. Jeyaram A, Jay SM. Preservation and storage stability of extracellular vesicles for therapeutic applications. AAPS J. 2018;20:1. https://doi. org/10.1208/s12248-017-0160-y.

49. Zhou H, Yuen PST, Pisitkun T, Gonzales PA, Yasuda H, Dear JW, et al. Collection, storage, preservation, and normalization of human urinary exosomes for biomarker discovery. Kidney Int. 2006;69:1471-6.

50. Muller L, Hong C-S, Stolz DB, Watkins SC, Whiteside TL. Isolation of biologically-active exosomes from human plasma. J Immunol Methods. 2014:411:55-65

51. Eitan E, Zhang S, Witwer KW, Mattson MP. Extracellular vesicle-depleted fetal bovine and human sera have reduced capacity to support cell growth. J Extracell Vesicles. 2015;4:26373.

52. Gardiner C, Vizio D, Di, Sahoo S, Théry C, Witwer KW, Wauben M, et al. Techniques used for the isolation and characterization of extracellular vesicles: results of a worldwide survey. J Extracell Vesicles. 2016;5:32945.

53. Kornilov R, Puhka M, Mannerström B, Hiidenmaa H, Peltoniemi H, Siljander $\mathrm{P}$, et al. Efficient ultrafiltration-based protocol to deplete extracellular vesicles from fetal bovine serum. J Extracell Vesicles. 2018;7:1422674.

54. Pirkmajer S, Chibalin AV. Serum starvation: caveat emptor. Am J Physiol Physiol. 2011;301:C272-9.

55. Shelke GV, Lässer C, Gho YS, Lötvall J. Importance of exosome depletion protocols to eliminate functional and RNA-containing extracellular vesicles from fetal bovine serum. J Extracell Vesicles. 2014;3:24783.

56. Szatanek R, Baran J, Siedlar M, Baj-Krzyworzeka M. Isolation of extracellular vesicles: determining the correct approach. Int J Mol Med. 2015:36:11-7.

57. Hugel B, Martínez MC, Kunzelmann C, Freyssinet J-M. Membrane microparticles: two sides of the coin. Physiology. 2005;20:22-7.

58. Avcı E, Balcı-Peynircioğlu B. An overview of exosomes: from biology to emerging roles in immune response. Acta Medica Cordoba. 2016:47:2-10.

59. Edgar JR. Q\&A: what are exosomes\&nbsp;exactly? BMC Biol. 2016;14:46.

60. Vlassov AV, Magdaleno S, Setterquist R, Conrad R. Exosomes: current knowledge of their composition, biological functions, and diagnostic and therapeutic potentials. Biochim Biophys Acta (BBA). 2012;1820:940-8.

61. Witwer KW, Buzás El, Bemis LT, Bora A, Lässer C, Lötvall J, et al. Standardization of sample collection, isolation and analysis methods in extracellular vesicle research. J Extracell Vesicles. 2013;2:20360. https:// doi.org/10.3402/jev.v2i0.20360.

62. Xu R, Greening DW, Zhu H-J, Takahashi N, Simpson RJ. Extracellular vesicle isolation and characterization: toward clinical application. J Clin Invest. 2016;126:1152-62.

63. Qin Y, Sun R, Wu C, Wang L, Zhang C. Exosome: a novel approach to stimulate bone regeneration through regulation of osteogenesis and angiogenesis. Int J Mol Sci. 2016;17:712.

64. Clayton A, Turkes A, Dewitt S, Steadman R, Mason MD, Hallett MB. Adhesion and signaling by B cell-derived exosomes: the role of integrins. FASEB J. 2004;18:977-9.

65. Morelli AE, Larregina AT, Shufesky WJ, Sullivan MLG, Stolz DB, Papworth $\mathrm{GD}$, et al. Endocytosis, intracellular sorting, and processing of exosomes by dendritic cells. Blood. 2004;104:3257-66.

66. Meckes DG, Raab-Traub N. Microvesicles and viral infection. J Virol. 2011;85:12844-54.

67. Alvarez-Erviti L, Seow Y, Yin H, Betts C, Lakhal S, Wood MJA. Delivery of siRNA to the mouse brain by systemic injection of targeted exosomes. Nat Biotechnol. 2011;29:341-5.

68. Kalani A, Tyagi A, Tyagi N. Exosomes: mediators of neurodegeneration, neuroprotection and therapeutics. Mol Neurobiol. 2014;49:590-600

69. Sun D, Zhuang X, Xiang X, Liu Y, Zhang S, Liu C, et al. A novel nanoparticle drug delivery system: the anti-inflammatory activity of curcumin is enhanced when encapsulated in exosomes. Mol Ther. 2010;18:1606-14.

70. Lai RC, Arslan F, Lee MM, Sze NSK, Choo A, Chen TS, et al. Exosome secreted by MSC reduces myocardial ischemia/reperfusion injury. Stem Cell Res. 2010;4:214-22.
71. Xin H, Li Y, Buller B, Katakowski M, Zhang Y, Wang X, et al. Exosomemediated transfer of miR-133b from multipotent mesenchymal stromal cells to neural cells contributes to neurite outgrowth. Stem Cells. 2012;30:1556-64.

72. Teixeira FG, Carvalho MM, Sousa N, Salgado AJ. Mesenchymal stem cells secretome: a new paradigm for central nervous system regeneration? Cell Mol Life Sci. 2013;70:3871-82.

73. Bruno S, Grange C, Collino F, Deregibus MC, Cantaluppi V, Biancone L, et al. Microvesicles derived from mesenchymal stem cells enhance survival in a lethal model of acute kidney injury. PLoS ONE. 2012;7:e33115.

74. Zhou Y, Xu H, Xu W, Wang B, Wu H, Tao Y, et al. Exosomes released by human umbilical cord mesenchymal stem cells protect against cisplatin-induced renal oxidative stress and apoptosis in vivo and in vitro. Stem Cell Res Ther. 2013;4:34.

75. van Balkom BWM, De Jong OG, Smits M, Brummelman J, den Ouden K, de Bree PM, et al. Endothelial cells require miR-214 to secrete exosomes that suppress senescence and induce angiogenesis in human and mouse endothelial cells. Blood J Am Soc Hematol. 2013;121:3997-4006.

76. Cantaluppi V, Biancone L, Figliolini F, Beltramo S, Medica D, Deregibus $M C$, et al. Microvesicles derived from endothelial progenitor cells enhance neoangiogenesis of human pancreatic islets. Cell Transplant. 2012;21:1305-20.

77. Ranghino A, Cantaluppi V, Grange C, Vitillo L, Fop F, Biancone L, et al. Endothelial progenitor cell-derived microvesicles improve neovascularization in a murine model of hindlimb ischemia. Int J Immunopathol Pharmacol. 2012;25:75-85.

78. Sahoo S, Klychko E, Thorne T, Misener S, Schultz KM, Millay M, et al. Exosomes from human CD34+ stem cells mediate their proangiogenic paracrine activity. Circ Res. 2011;109:724-8.

79. Bian S, Zhang L, Duan L, Wang X, Min Y, Yu H. Extracellular vesicles derived from human bone marrow mesenchymal stem cells promote angiogenesis in a rat myocardial infarction model. J Mol Med. 2014;92:387-97.

80. Zhang H-C, Liu X-B, Huang S, Bi X-Y, Wang H-X, Xie L-X, et al. Microvesicles derived from human umbilical cord mesenchymal stem cells stimulated by hypoxia promote angiogenesis both in vitro and in vivo. Stem Cells Dev. 2012;21:3289-97.

81. Mokarizadeh A, Delirezh N, Morshedi A, Mosayebi G, Farshid A-A, Mardani K. Microvesicles derived from mesenchymal stem cells: potent organelles for induction of tolerogenic signaling. Immunol Lett. 2012;147:47-54.

82. Zhang B, Yin Y, Lai RC, Tan SS, Choo ABH, Lim SK. Mesenchymal stem cells secrete immunologically active exosomes. Stem Cells Dev. 2014;23:1233-44.

83. Nakajima K, Kunimatsu R, Ando K, Ando T, Hayashi Y, Kihara T, et al. Comparison of the bone regeneration ability between stem cells from human exfoliated deciduous teeth, human dental pulp stem cells and human bone marrow mesenchymal stem cells. Biochem Biophys Res Commun. 2018;497:876-82.

84. Miura M, Gronthos S, Zhao M, Lu B, Fisher LW, Robey PG, et al. SHED: stem cells from human exfoliated deciduous teeth. Proc Natl Acad Sci. 2003;100:5807-12.

85. Saez DM, Sasaki RT, da Costa Neves A, da Silva MCP. Stem cells from human exfoliated deciduous teeth: a growing literature. Cells Tissues Organs. 2016;202:269-80.

86. Nooshabadi VT, Khanmohamadi M, Valipour E, Mahdipour S, Salati A, Malekshahi ZV, et al. Impact of exosome loaded chitosan hydrogel in wound repair and layered dermal reconstitution in mice animal model. J Biomed Mater Res A. 2020. https://doi.org/10.1002/jbm.a.36959.

87. Vakhshiteh F, Atyabi F, Ostad SN. Mesenchymal stem cell exosomes: a two-edged sword in cancer therapy. Int J Nanomed. 2019;14:2847.

88. Yu B, Zhang X, Li X. Exosomes derived from mesenchymal stem cells. Int J Mol Sci. 2014;15:4142-57.

89. Lőrincz ÁM, Timár Cl, Marosvári KA, Veres DS, Otrokocsi L, Kittel Á, et al. Effect of storage on physical and functional properties of extracellular vesicles derived from neutrophilic granulocytes. J Extracell Vesicles. 2014;3:25465. https://doi.org/10.3402/jev.v3.25465.

90. Jung JW, Kwon M, Choi JC, Shin JW, Park IW, Choi BW, et al. Familial occurrence of pulmonary embolism after intravenous, adipose tissuederived stem cell therapy. Yonsei Med J. 2013;54:1293-6. 
91. Zhang Y, Chopp M, Meng Y, Katakowski M, Xin H, Mahmood A, et al. Effect of exosomes derived from multipluripotent mesenchymal stromal cells on functional recovery and neurovascular plasticity in rats after traumatic brain injury. J Neurosurg. 2015;122:856-67.

92. Osugi M, Katagiri W, Yoshimi R, Inukai T, Hibi H, Ueda M. Conditioned media from mesenchymal stem cells enhanced bone regeneration in rat calvarial bone defects. Tissue Eng\&nbsp; A. 2012;18:1479-89.

93. Nagata M, Iwasaki K, Akazawa K, Komaki M, Yokoyama N, Izumi Y, et al. Conditioned medium from periodontal ligament stem cells enhances periodontal regeneration. Tissue Eng A. 2017;23:367-77.

94. Katagiri W, Kawai T, Osugi M, Sugimura-Wakayama Y, Sakaguchi $\mathrm{K}$, Kojima T, et al. Angiogenesis in newly regenerated bone by secretomes of human mesenchymal stem cells. Maxillofac Plast Reconstr Surg. 2017;39:1-8.

95. Takeuchi R, Katagiri W, Endo S, Kobayashi T. Exosomes from conditioned media of bone marrow-derived mesenchymal stem cells promote bone regeneration by enhancing angiogenesis. PLOS ONE. 2019;14:e0225472.

96. Ishizaka R, Hayashi Y, Iohara K, Sugiyama M, Murakami M, Yamamoto $T$, et al. Stimulation of angiogenesis, neurogenesis and regeneration by side population cells from dental pulp. Biomaterials. 2013;34:1888-97.

97. Diomede F, D'aurora M, Gugliandolo A, Merciaro I, Ettorre V, Bramanti $A$, et al. A novel role in skeletal segment regeneration of extracelIular vesicles released from periodontal-ligament stem cells. Int J Nanomed. 2018;13:3805.

98. Pizzicannella J, Gugliandolo A, Orsini T, Fontana A, Ventrella A, Mazzon $\mathrm{E}$, et al. Engineered extracellular vesicles from human periodontal-ligament stem cells increase VEGF/NEGFR2 expression during bone regeneration. Front Physiol. 2019;10:512.

99. Qin Y, Wang L, Gao Z, Chen G, Zhang C. Bone marrow stromal/stem cell-derived extracellular vesicles regulate osteoblast activity and differentiation in vitro and promote bone regeneration in vivo. Sci Rep. 2016;6:1-11.

100. Davies OG, Cooper PR, Shelton RM, Smith AJ, Scheven BA. A comparison of the in vitro mineralisation and dentinogenic potential of mesenchymal stem cells derived from adipose tissue, bone marrow and dental pulp. J Bone Miner Metab. 2015;33:371-82.

101. Basu J, Ludlow JW. Exosomes for repair, regeneration and rejuvenation. Expert Opin Biol Ther. 2016;16:489-506.

102. Li Y, Yang Y-Y, Ren J-L, XU F, Chen F-M, Li A. Exosomes secreted by stem cells from human exfoliated deciduous teeth contribute to functional recovery after traumatic brain injury by shifting microglia M1/M2 polarization in rats. Stem Cell Res Ther. 2017;8:198.

103. Ahmed NE-MB, Murakami M, Hirose Y, Nakashima M. Therapeutic potential of dental pulp stem cell secretome for Alzheimer's disease treatment: an in vitro study. Stem Cells Int. 2016. https://doi. org/10.1155/2016/8102478.

104. Yamaguchi T, Izumi Y, Nakamura Y, Yamazaki T, Shiota M, Sano S, et al. Repeated remote ischemic conditioning attenuates left ventricular remodeling via exosome-mediated intercellular communication on chronic heart failure after myocardial infarction. Int J Cardiol. 2015;178:239-46

105. Lee C, Mitsialis SA, Aslam M, Vitali SH, Vergadi E, Konstantinou G, et al. Exosomes mediate the cytoprotective action of mesenchymal stromal cells on hypoxia-induced pulmonary hypertension. Circulation. 2012;126:2601-11.

106. Ivica A, Ghayor C, Zehnder M, Valdec S, Weber FE. Pulp-derived exosomes in a fibrin-based regenerative root filling material. J Clin Med. 2020;9:491.

107. Huang C-C, Narayanan R, Alapati S, Ravindran S. Exosomes as biomimetic tools for stem cell differentiation: applications in dental pulp tissue regeneration. Biomaterials. 2016;111:103-15.

108. Chu C, Wei S, Wang Y, Wang Y, Man Y, Qu Y. Extracellular vesicle and mesenchymal stem cells in bone regeneration: recent progress and perspectives. J Biomed Mater Res A. 2019;107:243-50.

109. Grosso A, Burger MG, Lunger A, Schaefer DJ, Banfi A, Di Maggio N. It takes two to tango: coupling of angiogenesis and osteogenesis for bone regeneration. Front Bioeng Biotechnol. 2017;5:68.

110. Salomon C, Ryan J, Sobrevia L, Kobayashi M, Ashman K, Mitchell $M$, et al. Exosomal signaling during hypoxia mediates microvascular endothelial cell migration and vasculogenesis. PLoS ONE. 2013;8:e68451.

111. Cui Y, Luan J, Li H, Zhou X, Han J. Exosomes derived from mineralizing osteoblasts promote ST2 cell osteogenic differentiation by alteration of microRNA expression. FEBS Lett. 2016;590:185-92.

112. Narayanan R, Huang C-C, Ravindran S. Hijacking the cellular mail: exosome mediated differentiation of mesenchymal stem cells. Stem Cells Int. 2016. https://doi.org/10.1155/2016/3808674.

113. Wang Z, Ding L, Zheng X-L, Wang H-X, Yan H-M. DC-derived exosomes induce osteogenic differentiation of mesenchymal stem cells. Zhongguo shi yan xue ye xue za zhi. 2014;22:600-4.

114. Li W, Liu Y, Zhang P, Tang Y, Zhou M, Jiang W, et al. Tissue-engineered bone immobilized with human adipose stem cells-derived exosomes promotes bone regeneration. ACS Appl Mater Interfaces. 2018;10:5240-54.

115. Lu Z, Chen Y, Dunstan C, Roohani-Esfahani S, Zreiqat H. Priming adipose stem cells with tumor necrosis factor-alpha preconditioning potentiates their exosome efficacy for bone regeneration. Tissue Eng A. 2017;23:1212-20.

116. Ekström K, Omar O, Graneli C, Wang X, Vazirisani F, Thomsen P. Monocyte exosomes stimulate the osteogenic gene expression of mesenchymal stem cells. PLoS ONE. 2013;8:e75227.

117. Ge M, Ke R, Cai T, Yang J, MuX. Identification and proteomic analysis of osteoblast-derived exosomes. Biochem Biophys Res Commun. 2015;467:27-32.

118. Inder KL, Ruelcke JE, Petelin L, Moon H, Choi E, Rae J, et al. Cavin-1/PTRF alters prostate cancer cell-derived extracellular vesicle content and internalization to attenuate extracellular vesicle-mediated osteoclastogenesis and osteoblast proliferation. J Extracell Vesicles. 2014;3:23784.

119. Kawakubo A, Matsunaga T, Ishizaki H, Yamada S, Hayashi Y. Zinc as an essential trace element in the acceleration of matrix vesicles-mediated mineral deposition. Microsc Res Tech. 2011;74:1161-5.

120. Raimondi L, De Luca A, Amodio N, Manno M, Raccosta S, Taverna S, et al. Involvement of multiple myeloma cell-derived exosomes in osteoclast differentiation. Oncotarget. 2015;6:13772.

121. Huynh N, VonMoss L, Smith D, Rahman I, Felemban MF, Zuo J, et al. Characterization of regulatory extracellular vesicles from osteoclasts. J Dent Res. 2016;95:673-9. https://doi.org/10.1177/0022034516633189.

122. Zhang J, Liu X, Li H, Chen C, Hu B, Niu X, et al. Exosomes/tricalcium phosphate combination scaffolds can enhance bone regeneration by activating the PI3K/Akt signaling pathway. Stem Cell Res Ther. 2016;7:136. https://doi.org/10.1186/s13287-016-0391-3.

123. Xie $H$, Wang Z, Zhang L, Lei Q, Zhao A, Wang $H$, et al. Extracellular vesicle-functionalized decalcified bone matrix scaffolds with enhanced pro-angiogenic and pro-bone regeneration activities. Sci Rep. 2017;7:45622.

124. Wei F, Li M, Crawford R, Zhou Y, Xiao Y. Exosome-integrated titanium oxide nanotubes for targeted bone regeneration. Acta Biomater. 2019:86:480-92.

125. Katagiri W, Osugi M, Kawai T, Ueda M. Novel cell-free regeneration of bone using stem cell-derived growth factors. Int J Oral Maxillofac Implants. 2013;28:1009-16.

126. Ando Y, Matsubara K, Ishikawa J, Fujio M, Shohara R, Hibi H, et al. Stem cell-conditioned medium accelerates distraction osteogenesis through multiple regenerative mechanisms. Bone. 2014;61:82-90.

127. Ogata K, Katagiri W, Osugi M, Kawai T, Sugimura Y, Hibi H, et al. Evaluation of the therapeutic effects of conditioned media from mesenchymal stem cells in a rat bisphosphonate-related osteonecrosis of the jaw-like model. Bone. 2015;74:95-105.

128. Fujio M, Xing Z, Sharabi N, Xue Y, Yamamoto A, Hibi H, et al. Conditioned media from hypoxic-cultured human dental pulp cells promotes bone healing during distraction osteogenesis. J Tissue Eng Regen Med. 2017;11:2116-26.

129. Xu J, Wang B, Sun Y, Wu T, Liu Y, Zhang J, et al. Human fetal mesenchymal stem cell secretome enhances bone consolidation in distraction osteogenesis. Stem Cell Res Ther. 2016;7:134

130. Wang B, Lee WY-W, Huang B, Zhang J-F, Wu T, Jiang X, et al. Secretome of human fetal mesenchymal stem cell ameliorates replicative senescence. Stem Cells Dev. 2016;25:1755-66. 
131. Zhang S, Chu WC, Lai RC, Lim SK, Hui JHP, Toh WS. Exosomes derived from human embryonic mesenchymal stem cells promote osteochondral regeneration. Osteoarthr Cartil. 2016;24:2135-40.

132. Furuta T, Miyaki S, Ishitobi H, Ogura T, Kato Y, Kamei N, et al. Mesenchymal stem cell-derived exosomes promote fracture healing in a mouse model. Stem Cells Transl Med. 2016;5:1620-30.

133. Qi X, Zhang J, Yuan H, Xu Z, Li Q, Niu X, et al. Exosomes secreted by human-induced pluripotent stem cell-derived mesenchymal stem cells repair critical-sized bone defects through enhanced angiogenesis and osteogenesis in osteoporotic rats. Int J Biol Sci. 2016;12:836-49.

134. Zhao R, Li F-Q, Tian L-L, Shang D-S, Guo Y, Zhang J-R, et al. Comprehensive analysis of the whole coding and non-coding RNA transcriptome expression profiles and construction of the circRNA-InCRNA coregulated ceRNA network in laryngeal squamous cell carcinoma. Funct Integr Genom. 2019;19:109-21.

135. Paschalidis T, Bakopoulou A, Papa P, Leyhausen G, Geurtsen W, Koidis P. Dental pulp stem cells' secretome enhances pulp repair processes and compensates TEGDMA-induced cytotoxicity. Dent Mater. 2014;30:e405-18.

136. Diomede F, Gugliandolo A, Scionti D, Merciaro I, Cavalcanti MFXB, Mazzon E, et al. Biotherapeutic effect of gingival stem cells conditioned medium in bone tissue restoration. Int J Mol Sci. 2018;19:329.

137. Diomede F, Gugliandolo A, Cardelli P, Merciaro I, Ettorre V, Traini T, et al. Three-dimensional printed PLA scaffold and human gingival stem cellderived extracellular vesicles: a new tool for bone defect repair. Stem Cell Res Ther. 2018;9:104.

138. Diomede F, D'Aurora M, Gugliandolo A, Merciaro I, Ettorre V, Bramanti $A$, et al. A novel role in skeletal segment regeneration of extracellular vesicles released from periodontal-ligament stem cells. Int J Nanomed. 2018;13:3805-25.

139. Kumar A, Kumar $\vee$, Rattan $\vee$, Jha $\vee$, Bhattacharyya S. Secretome proteins regulate comparative osteogenic and adipogenic potential in bone marrow and dental stem cells. Biochimie. 2018;155:129-39.

140. Davis C, Dukes A, Drewry M, Helwa I, Johnson MH, Isales CM, et al. MicroRNA-183-5p increases with age in bone-derived extracellular vesicles, suppresses bone marrow stromal (stem) cell proliferation, and induces stem cell senescence. Tissue Eng A. 2017;23:1231-40.

141. Wen S, Dooner M, Cheng Y, Papa E, Del Tatto M, Pereira M, et al. Mesenchymal stromal cell-derived extracellular vesicles rescue radiation damage to murine marrow hematopoietic cells. Leukemia. 2016;30:2221-31.

142. Deng $L$, Wang Y, Peng Y, Wu Y, Ding Y, Jiang Y, et al. Osteoblast-derived microvesicles: a novel mechanism for communication between osteoblasts and osteoclasts. Bone. 2015;79:37-42.

143. Ramachandran A, Ravindran S, Huang C-C, George A. TGF beta receptor II interacting protein-1, an intracellular protein has an extracellular role as a modulator of matrix mineralization. Sci Rep. 2016;6:37885.

144. Li D, Liu J, Guo B, Liang C, Dang L, Lu C, et al. Osteoclast-derived exosomal miR-214-3p inhibits osteoblastic bone formation. Nat Commun. 2016;7:1-16.

145. Kolhe R, Hunter M, Liu S, Jadeja RN, Pundkar C, Mondal AK, et al. Gender-specific differential expression of exosomal miRNA in synovial fluid of patients with osteoarthritis. Sci Rep. 2017;7:1-14.

146. Chen C, Wang D, Moshaverinia A, Liu D, Kou X, Yu W, et al. Mesenchymal stem cell transplantation in tight-skin mice identifies miR-151-5p as a therapeutic target for systemic sclerosis. Cell Res. 2017;27:559-77.

147. Xu J-F, Yang G, Pan X-H, Zhang S-J, Zhao C, Qiu B-S, et al. Altered microRNA expression profile in exosomes during osteogenic differentiation of human bone marrow-derived mesenchymal stem cells. PLoS ONE. 2014;9:e114627

148. Wang J, Liu S, Li J, Zhao S, Yi Z. Roles for miRNAs in osteogenic differentiation of bone marrow mesenchymal stem cells. Stem Cell Res Ther. 2019;10:197. https://doi.org/10.1186/s13287-019-1309-7.

149. Chen S, Tang Y, Liu Y, Zhang P, Lv L, Zhang X, et al. Exosomes derived from miR-375-overexpressing human adipose mesenchymal stem cells promote bone regeneration. Cell Prolif. 2019;52:e12669.

150. Jia Y, Zhu Y, Qiu S, Xu J, Chai Y. Exosomes secreted by endothelial progenitor cells accelerate bone regeneration during distraction osteogenesis by stimulating angiogenesis. Stem Cell Res Ther. 2019;10:1-13.

151. Liang B, Liang J-M, Ding J-N, Xu J, Xu J-G, Chai Y-M. Dimethyloxaloylglycine-stimulated human bone marrow mesenchymal stem cell-derived exosomes enhance bone regeneration through angiogenesis by targeting the AKT/mTOR pathway. Stem Cell Res Ther. 2019;10:335.

152. Qin Y, Zhang C. Endothelial progenitor cell-derived extracellular vesiclemeditated cell-to-cell communication regulates the proliferation and osteoblastic differentiation of bone mesenchymal stromal cells. Mol Med Rep. 2017;16:7018-24. https://doi.org/10.3892/mmr.2017.7403.

153. Wang M, Li J, Ye Y, He S, Song J. SHED-derived conditioned exosomes enhance the osteogenic differentiation of PDLSCs via Wnt and BMP signaling in vitro. Differentiation. 2020;111:1-11.

154. Sun R, Xu S, Wang Z. Rat sinus mucosa-and periosteum-derived exosomes accelerate osteogenesis. J Cell Physiol. 2019;234:21947-61.

155. Luo Z-W, Liu Y-W, Rao S-S, Yin H, Huang J, Chen C-Y, et al. Aptamerfunctionalized exosomes from bone marrow stromal cells target bone to promote bone regeneration. Nanoscale. 2019;11:20884-92.

156. Guo S-C, Tao S-C, Yin W-J, Qi X, Sheng J-G, Zhang C-Q. Exosomes from human synovial-derived mesenchymal stem cells prevent glucocorticoid-induced osteonecrosis of the femoral head in the rat. Int J Biol Sci. 2016;12:1262-72.

157. Jia Y, Qiu S, Xu J, Kang Q, Chai Y. Exosomes secreted by young mesenchymal stem cells promote new bone formation during distraction osteogenesis in older rats. Calcif Tissue Int. 2020;106:509-17. https:// doi.org/10.1007/s00223-019-00656-4.

158. Kuang M, Huang Y, Zhao X, Zhang R, Ma J, Wang D, et al. Exosomes derived from Wharton's jelly of human umbilical cord mesenchymal stem cells reduce osteocyte apoptosis in glucocorticoid-induced osteonecrosis of the femoral head in rats via the miR-21-PTEN-AKT signalling pathway. Int J Biol Sci. 2019;15:1861-71.

159. Li H, Liu D, Li C, Zhou S, Tian D, Xiao D, et al. Exosomes secreted from mutant-HIF-1a-modified bone-marrow-derived mesenchymal stem cells attenuate early steroid-induced avascular necrosis of femoral head in rabbit. Cell Biol Int. 2017:41:1379-90. https://doi.org/10.1002/ cbin. 10869

160. Li R, Chen C, Zheng R-Q, Zou L, Hao G-L. Influences of hucMSCexosomes on VEGF and BMP-2 expression in SNFH rats. Eur Rev Med Pharmacol Sci. 2019;23:2935-43.

161. Li X, Zheng Y, Hou L, Zhou Z, Huang Y, Zhang Y, et al. Exosomes derived from maxillary BMSCs enhanced the osteogenesis in iliac BMSCs. Oral Dis. 2020;26:131-44. https://doi.org/10.1111/odi.13202.

162. Liao W, Ning Y, Xu H-J, Zou W-Z, Hu J, Liu X-Z, et al. BMSC-derived exosomes carrying microRNA-122-5p promote proliferation of osteoblasts in osteonecrosis of the femoral head. Clin Sci. 2019;133:1955-75.

163. Liu X, Li Q, Niu X, Hu B, Chen S, Song W, et al. Exosomes secreted from human-induced pluripotent stem cell-derived mesenchymal stem cells prevent osteonecrosis of the femoral head by promoting angiogenesis. Int J Biol Sci. 2017;13:232-44.

164. Liu W, Li L, Rong Y, Qian D, Chen J, Zhou Z, et al. Hypoxic mesenchymal stem cell-derived exosomes promote bone fracture healing by the transfer of miR-126. Acta Biomater. 2020;103:196-212.

165. Xu H-J, Liao W, Liu X-Z, Hu J, Zou W-Z, Ning Y, et al. Down-regulation of exosomal microRNA-224-3p derived from bone marrow-derived mesenchymal stem cells potentiates angiogenesis in traumatic osteonecrosis of the femoral head. FASEB J. 2019;33:8055-68. https://doi. org/10.1096/f. 201801618RRR.

166. Xu T, Luo Y, Wang J, Zhang N, Gu C, Li L, et al. Exosomal miRNA-128-3p from mesenchymal stem cells of aged rats regulates osteogenesis and bone fracture healing by targeting Smad5. J Nanobiotechnol. 2020;18:47. https://doi.org/10.1186/s12951-020-00601-w.

167. Yang B, Kuang M, Kang J, Zhao J, Ma J, Ma X. Human umbilical cord mesenchymal stem cell-derived exosomes act via the miR-1263/Mob1/ Hippo signaling pathway to prevent apoptosis in disuse osteoporosis. Biochem Biophys Res Commun. 2020;524:883-9.

168. Zhang $L$, Jiao G, Ren S, Zhang X, Li C, Wu W, et al. Exosomes from bone marrow mesenchymal stem cells enhance fracture healing through the promotion of osteogenesis and angiogenesis in a rat model of nonunion. Stem Cell Res Ther. 2020;11:38. https://doi.org/10.1186/s1328 7-020-1562-9.

169. Zhou J, Liu H-X, Li S-H, Gong Y-S, Zhou M-W, Zhang J-H. Effects of human umbilical cord mesenchymal stem cells-derived exosomes on fracture healing in rats through the Wnt signaling pathway. Eur Rev Med Pharmacol Sci. 2019;23:4954-60. 
170. Zuo R, Liu M, Wang Y, Li J, Wang W, Wu J, et al. BM-MSC-derived exosomes alleviate radiation-induced bone loss by restoring the function of recipient BM-MSCs and activating Wnt/ $\beta$-catenin signaling. Stem Cell Res Ther. 2019;10:30. https://doi.org/10.1186/s1328 7-018-1121-9.

171. Golub EE. Biomineralization and matrix vesicles in biology and pathology. In: Seminars in immunopathology. New York: Springer; 2011. p. 409-17.

172. Xie Y, Chen Y, Zhang L, Ge W, Tang P. The roles of bone-derived exosomes and exosomal micro RNA s in regulating bone remodelling. $J$ Cell Mol Med. 2017;21:1033-41.

173. Tan SHS, Wong JRY, Sim SJY, Tjio CKE, Wong KL, Chew JRJ, et al. Mesenchymal stem cell exosomes in bone regenerative strategies-a systematic review of preclinical studies. Mater Today Bio. 2020;7:100067.

174. Ji L, Bao L, Gu Z, Zhou Q, Liang Y, Zheng Y, et al. Comparison of immunomodulatory properties of exosomes derived from bone marrow mesenchymal stem cells and dental pulp stem cells. Immunol Res. 2019;67:432-42.

175. Ismail N, Wang Y, Dakhlallah D, Moldovan L, Agarwal K, Batte K, et al. Macrophage microvesicles induce macrophage differentiation and miR-223 transfer. Blood J Am Soc Hematol. 2013;121:984-95.

176. Chu C, Deng J, Sun X, Qu Y, Man Y. Collagen membrane and immune response in guided bone regeneration: recent progress and perspectives. Tissue Eng Part B Rev. 2017;23:421-35.

177. Yu S, Liu C, Su K, Wang J, Liu Y, Zhang L, et al. Tumor exosomes inhibit differentiation of bone marrow dendritic cells. J Immunol. 2007; 178:6867-75.

178. Chew JRJ, Chuah SJ, Teo KYW, Zhang S, Lai RC, Fu JH, et al. Mesenchymal stem cell exosomes enhance periodontal ligament cell functions and promote periodontal regeneration. Acta Biomater. 2019;89:252-64.

179. Mohammed E, Khalil E, Sabry D. Effect of adipose-derived stem cells and their exo as adjunctive therapy to nonsurgical periodontal treatment: a histologic and histomorphometric study in rats. Biomolecules. 2018;8:167.

180. Nakayama H, lohara K, Hayashi Y, Okuwa Y, Kurita K, Nakashima M. Enhanced regeneration potential of mobilized dental pulp stem cells from immature teeth. Oral Dis. 2017;23:620-8.

181. Kawai T, Katagiri W, Osugi M, Sugimura Y, Hibi H, Ueda M. Secretomes from bone marrow-derived mesenchymal stromal cells enhance periodontal tissue regeneration. Cytotherapy. 2015;17:369-81.

182. Qiu J, Wang X, Zhou H, Zhang C, Wang Y, Huang J, et al. Enhancement of periodontal tissue regeneration by conditioned media from gingiva-derived or periodontal ligament-derived mesenchymal stem cells: a comparative study in rats. Stem Cell Res Ther. 2020;1 1:42.

183. Liu Y, Zheng Y, Ding G, Fang D, Zhang C, Bartold PM, et al. Periodontal ligament stem cell-mediated treatment for periodontitis in miniature swine. Stem Cells. 2008;26:1065-73.

184. Maeda H, Tomokiyo A, Fujii S, Wada N, Akamine A. Promise of periodontal ligament stem cells in regeneration of periodontium. Stem Cell Res Ther. 2011;2:33.

185. Zhang S, Chuah SJ, Lai RC, Hui JHP, Lim SK, Toh WS. MSC exosomes mediate cartilage repair by enhancing proliferation, attenuating apoptosis and modulating immune reactivity. Biomaterials. 2018;156:16-27.

186. Cochran DL. Inflammation and bone loss in periodontal disease. J Periodontol. 2008;79:1569-76.

187. Xu R, Rai A, Chen M, Suwakulsiri W, Greening DW, Simpson RJ. Extracellular vesicles in cancer-implications for future improvements in cancer care. Nat Rev Clin Oncol. 2018;15:617.

188. Mianehsaz E, Mirzaei HR, Mahjoubin-Tehran M, Rezaee A, Sahebnasagh $\mathrm{R}$, Pourhanifeh $\mathrm{MH}$, et al. Mesenchymal stem cell-derived exosomes: a new therapeutic approach to osteoarthritis? Stem Cell Res Ther. 2019;10:340.

189. Vallabhaneni KC, Penfornis P, Dhule S, Guillonneau F, Adams KV, Mo YY, et al. Extracellular vesicles from bone marrow mesenchymal stem/ stromal cells transport tumor regulatory microRNA, proteins, and metabolites. Oncotarget. 2015;6:4953.

190. Peinado H, Alečković M, Lavotshkin S, Matei I, Costa-Silva B, MorenoBueno $G$, et al. Melanoma exosomes educate bone marrow progenitor cells toward a pro-metastatic phenotype through MET. Nat Med. 2012;18:883.

191. Lobb RJ, Becker M, Wen Wen S, Wong CSF, Wiegmans AP, Leimgruber A, et al. Optimized exosome isolation protocol for cell culture supernatant and human plasma. J Extracell Vesicles. 2015:4:27031.

192. Riau AK, Ong HS, Yam GHF, Mehta JS. Sustained delivery system for stem cell-derived exosomes. Front Pharmacol. 2019. https://doi. org/10.3389/fphar.2019.01368.

193. Lai CP, Mardini O, Ericsson M, Prabhakar S, Maguire CA, Chen JW, et al. Dynamic biodistribution of extracellular vesicles in vivo using a multimodal imaging reporter. ACS Nano. 2014;8:483-94.

\section{Publisher's note}

Springer Nature remains neutral with regard to jurisdictional claims in published maps and institutional affiliations.
Ready to submit your research? Choose BMC and benefit from:

- fast, convenient online submission

- thorough peer review by experienced researchers in your field

- rapid publication on acceptance

- support for research data, including large and complex data types

- gold Open Access which fosters wider collaboration and increased citations

- maximum visibility for your research: over 100M website views per year

At BMC, research is always in progress.

Learn more biomedcentral.com/submissions 